\title{
Heavy Metal Contamination in Forest Reserved Soils Crossed by Roads, its Ecological Risks, and their Effects on Tree Biomass Stocking Potential
}

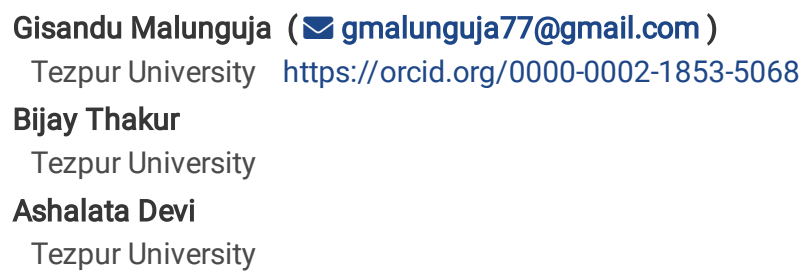

\section{Research Article}

Keywords: Ecological risk, environmental pollution; forest ecology; heavy metals, pollution indices

Posted Date: July 30th, 2021

DOI: https://doi.org/10.21203/rs.3.rs-762158/v1

License: (c) (i) This work is licensed under a Creative Commons Attribution 4.0 International License. Read Full License 


\section{Abstract}

Metal contaminants such as Cadmium, Chromium, Nickel, and Lead are released and deposited in Reserved Forest soils as a result of heavily travelled roads. Their pollution interrupts the biogeochemical cycle in the natural environment, affecting plant productivity. However, this pollution's source, their ecological risks, and its effects on tree biomass productivity have yet to be examined. In order to examine this, an ecological study was conducted in two Assam Reserved Forests that are crossed by the National Highway (NH-15). Several ecological risk indices were used to assess potential ecological risks. Metal impacts on tree biomass stocks were predicted using regression analysis and Pearson's coefficient. The results showed that metal concentrations in soil samples collected near roads were much higher than those away from roads. However, the overall mean concentration was within the Indian guidelines. Indices of soil contaminations and pollutions ranged from mildly contaminated to highly contaminated and from low polluted to highly polluted soils. The $\mathrm{Cd}(88.97 \%)$, and $\mathrm{Pb}(52.61 \%)$ were revealed to be highly the main contaminating and sources of pollution and ecological danger in the surface soils. The strongest Pearson correlation coefficients between $\mathrm{Cd}-\mathrm{Cr}$ ( $94 \%)$, Cd-Ni (74\%), Cd-Pb (97\%), Cr-Ni (88\%), Cr-Pb (90\%), and $\mathrm{Ni-Pb}$ (76\%) suggest that metals are very comparable. While the strong negative relationships between tree biomass stock and metals, implying that metals are vital factors affecting tree biomass productivity. Thus, conservationists, ecologists, and policymakers must devise effective mitigation strategies for vehicular emission and car discharge caused by traffic passing through reserved forests.

\section{Highlights}

- metal pollution accumulations in surface soils are exacerbated by fast-moving traffic and its exhaust discharge highways in urban conserved forests.

- these were thoroughly investigated and discovered to have a substantial impact on environmental safety and ecological dangers.

- Metals like ( $\mathrm{Cd})$, chromium, nickel (Ni), and lead $(\mathrm{Pb})$ were discovered to be the most contaminating elements in reserved forests, with considerable impacts on ecological safety and plant productivity.

- metals portrayed a strong correlation of: $\mathrm{Cd}-\mathrm{Cr}$ (94\%) Cd-Ni (74\%), Cd-Pb (97\%) Cr-Ni (88\%) Cr-Pb (90\%) and Ni-Pb (76\%) suggesting the common source.

- metals demonstrated a negative correlation with tree stocking potential: TB-Pb (-80\%), TB-Ni (-79\%), TB-Cr (-76\%), and TB-Cd (-71\%), showing that metals had a considerable impact on tree stocking and productivity potential.

\section{Introduction}

The discharge of metal pollutants from automotive lubricants, vehicular emissions, and frequent road repair in heavily and quickly-traveled National highways that pass through Reserved Forests (RFs), all contribute to the accumulation of metal pollutants in surface soils (Rai et al. 2014; Ngaba and Mgelwa, 2020). This can be a valuable indicator of pollution levels and impacts on the environment (Devi et al. 2019), which can significantly impact plant productivity, particularly tree biomass stocking potential (Siddiqui et al. 2020). Metal deposition in many components of the environment, including soils, water, wetlands, and air, is of global concern today (Shi et al. 2019; Adimalla 2020; Dutta et al. 2021). Metal pollutants, such as nickel ( $\mathrm{Ni})$, iron (Fe), manganese (Mn), zinc ( $\mathrm{Zn})$, copper ( $\mathrm{Cu})$, chromium ( $\mathrm{Cr})$, arsenic $(\mathrm{As})$, mercury $(\mathrm{Hg})$, lead $(\mathrm{Pb})$, and cadmium (Cd), has become a serious global concern (Carvalho et al. 2020; Singh et al. 2020). Their contamination of many elements of the environment and ecosystem disrupts the natural biogeochemical cycle (Borah et al. 2018; Kumar et al. 2019; Guarda et al. 2020). They are considered the most dangerous because of their non-biodegradability, ecological risks, toxicity, biogeochemical recycling, extended biological half-lives, and persistence (Bhatia et al. 2015; Sharma et al. 2018; Kaur et al. 2020), and some are poisonous even at extremely low doses. They can affect plant growth and alter their productivity (Sharma 2017; Singh et al. 2020). However, extensive ecological studies to assess levels and ecological risks of metal contaminants, particularly in high-trafficked roadways, in connection to plant productivity are rare in the literature.

Highways that pass through protected forest ecosystems such as National parks (NP), Wildlife sanctuaries (WLS), Biosphere reserves (BRs), and Reserve forests (RFs) have been identified as significant polluters (Gowd et al. 2010). They are also the source of other metals in the environment (Sarma et al. 2017; Devi et al. 2019; Ngaba and Mgelwa, 2020). The principal sources of heavy metal pollution in urban forestry are road traffic density patterns, automotive parts and their exhaust discharges, boiler and emission, tire wear and tear, and brake lining wears (Rai et al. 2014 ; Kaur et al. 2020). Due to high levels of trace metals in materials and chemicals used, activities such as road or bridge renovation, construction, and maintenance along forest habitats lead to metal deposition in soil surfaces (Bhatia et al. 2015; Siddiqui et al. 2020; Dutta et al. 2021). This has become a severe worry in many developing countries, with an alarming increase (Hu et al. 2013; Sarma et al. 2017; Devi et al. 2019). As a result, rising vehicle counts and fast-moving traffic have resulted in a significant increase in the contribution of heavy metal deposition in natural ecosystems (Singh et al. 2020).

On the other hand, road construction and maintenance are among the most common sources of metal deposition and natural landscape change (Borah et al. 2018). This alters the physical environment and causes edge effects that last well beyond the building period of the road (Trombulak 
and Frissell 2000). According to studies, contamination of soils and plant parts is higher near high-traffic roads and decreases within 20 meters or can occur up to 200 meters away from the roadsides (Trombulak and Frissell 2000). According to (Sarma et al. 2017), vehicle-induced metal pollution changes leaf epidermal characteristics and leaf pigment concentration, all of which impede plant photosynthesis. Plants exposed to metals for an extended period may have reduced leaf growth and $\mathrm{CO}_{2}$ assimilation activity (Khanam et al. 2020). Similarly, (Singh et al. 2020) pointed out that metal concentrations in surface soils and plant tissue caused by vehicular movements harm photosynthesis, transpiration, and productivity. Dust is mobilized and distributed by heavily travelled roadways, and when it settles on plants, it hinders photosynthesis, respiration, and transpiration, causing bodily damage on plant structure (Trombulak and Frissell 2000; Devi et al. 2019). Metal contaminants in soil are causing increasing concern around the world. Their toxicity, as well as their introduction into the food chain and the hazards that come with it (Adhikari and Bhattacharyya 2015). Metals accumulating in the terrestrial ecosystem beyond specified limits can harm soil hydrology and biota (Kumar et al. 2019; Guarda et al. 2020). They can cause chemical interactions that have synergistic effects on plant productivity, and as a result, their toxicity poses a risk to humans via the food chain (Fajardo et al. 2020). They are sensitive markers of pollution and a predictor of mineralogy and soil fertility (Adhikari and Bhattacharyya 2015). Even in low quantities, some heavy metals, in particular, may be exceedingly harmful to the environment. These activities alter soils' physical and chemical qualities, resulting in changes in the soil's natural behavior. As a result, the quality of groundwater may worsen, and the development pattern, morphology, and metabolism of microorganisms and the ecosystem's nutrient recycling mechanisms (Dutta et al. 2021). Metal concentrations have a big impact on physical properties like soil density, water holding capacity, organic carbon content, cation exchange capacity, texture, $\mathrm{pH}$, and electrical conductivity in every environment (Rai et al. 2014; Trombulak and Frissell 2000). The worst-case scenario is that these harmful substances penetrate the food chain, causing direct health effects on individuals (Devi et al. 2019).

Metal pollutants come from a variety of sources, which can be classified as either natural (lithogenic inputs via geochemical and chemical processes) or anthropogenic (urbanization, industrialization, agricultural expansion, livestock, dumping), (Alloway 2013; Adhikari and Bhattacharyya 2015; Devi et al. 2019; Khanam et al. 2020). The soil is the principal sink for all of these sources, as it is the most major natural potential sink for a variety of essential and non-essential metals (Adimalla 2020; Ng et al. 2016). Essential metal pollutants are those that living organisms require in trace amounts to support their metabolic functions (e.g., nickel (Ni), iron (Fe), manganese (Mn), zinc (Zn), and copper (Cu), whereas non-essential metals (e.g., chromium (Cr), arsenic (As), mercury (Hg), lead (Pb), and cadmium (Cd)) are not required for living organisms' growth ( $\mathrm{Ng}$ et al. 2016). These metals are expected to provide a direct and long-term threat to the ecosystem if they are present in quantities higher than naturally occurring values. As a result, metal has gotten a lot of attention worldwide, and quantifying the accessible amounts in various ecosystems is seen as an essential undertaking. Metals that have accumulated on the surface of soils have become a severe problem (Sharma et al. 2018). They go through metabolic, geochemical, and chemical processes, which naturally enrich the soil with varying degrees of toxicity (Adhikari and Bhattacharyya 2015). The ecosystem's metal concentrations may be tolerated by the ecosystem at low levels but can become detrimental at larger levels (Gowd et al. 2010).

The United States Environmental Protection Agency (USEPA) categorized metals according to their toxicity priority (USEPA 1999; Shi et al. 2019). Metals including arsenic (As), cadmium (Cd), chromium ( $\mathrm{Cr}$ ), nickel (Ni), and lead (Pb) are known to be highly poisonous when it comes to their potential effects on the environment and ecology (Protano et al. 2014). Several studies have been carried out to determine the levels of metal contaminants and the ecological threats they pose in India's various ecosystems and land-use regimes (Chetia et al. 2011; Sarkar et al. 2011; Singh et al. 2015; Jha et al. 2016; Singh et al. 2017; Sharma et al. 2018; Kaur et al. 2020; Siddiqui et al. 2020; Kaushik et al. 2021; Mishra and Kumar 2021). However, few localized assessments of metal pollution in protected urban forest surface soil and their ecological risks with respect to tree biomass stocking potential. Even the limited literature available, from heavily trafficked roads passing through protected areas, focuses primarily on the effects of dust deposition and air pollution (Rai et al. 2014; Singh et al. 2015; Sarma et al. 2017; Devi et al. 2019; Singh et al. 2020; Siddiqui et al. 2020). In India, the contribution of heavily used highways passing through urban Reserved Forests on heavy metal emission, ecological risk, and influence on tree biomass stocking potentials are seldom observed. Therefore, we conducted an experiment in two RFs of Tezpur town, namely Balipara and Bhomoraguri, in Assam, a northeastern Indian state, to: (i) delineate the level of four metal pollutants (Cd, $\mathrm{Cr}$, $\mathrm{Ni}$, and $\mathrm{Pb}$ ) in surface soil; (ii) quantify their ecological risk levels using various indices; and (iii) predict the effects of metal pollutants on tree biomass productivity and stocking potential. To achieve these objectives, we compared responses at control sites (about 200 metres away from the roadside within the RFs) with little or no exposure to vehicular emissions.

\section{Materials And Methods}

\section{Description and selection of the study sites}

The present study was conducted in two RFs of Tezpur town in Assam, namely Balipara and Bhomoraguri. The National Highway No. 15 (NH-15), which connects all of the state's major cities and is one of the busiest highways for motorized freight transit, runs right via the two RFs throughout the year. The highway is known for its high traffic density and regular movement of heavy-duty vehicles from all northeast India. The two RFs of Balipara and Bhomoraguri were chosen due to the presence of a National Highway passing through, and other activities such as an ongoing bridge construction project and frequent river overflow caused by the Brahmaputra River. The study locations are depicted in detail in Fig. 1. 
The two RFs, are found near Tezpur town in the Sonitpur district of Assam. The district is one of the state's 33 administrative districts, located in the north of the central Brahmaputra valley, between $92^{\circ} 16^{\prime} \mathrm{E}$ and $93^{\circ} 43^{\prime} \mathrm{E}$ longitudes, and $26^{\circ} 30^{\prime} \mathrm{N}$ to $27^{\circ} \mathrm{N}$ latitudes, with an average elevation of 70 to 75 meters above mean sea level (Nath et al. 2013). RFs cover around $17.57 \%$ of the district, covering an area of 935.38 square kilometres (Baruah et al. 2007). The district's northern and southern limits are bounded by the Himalayan foothills and the Brahmaputra River (Nath et al. 2013). The district is located in a subtropical climatic zone with a monsoon climate. Summers are hot and humid, with temperatures ranging from 7 to $36^{\circ} \mathrm{C}$ on average (Saxena et al. 2014). The rainy season starts early in April, with an annual average plumage of between 170 and $220 \mathrm{~cm}$ (Nath et al. 2013), influencing the region's climate (Baruah et al. 2007). The rain falls heavily, a blessing and a curse for the people (Baruah et al. 2007; Nath et al. 2013).

\section{Sampling and sample collection}

Soil and tree samples were obtained at two sampling sites (near the roadside and away from the roadside) in the RFs. To compare the answers, the sites away from the roadway was considered as a control site, its samples were taken at a distance of about 200 meters away from the roadside (adopted from Trombulak and Frissell 2000; Singh et al. 2020). The 200-meter distance was deemed sufficient to be free or minimally exposed to automobile exhaust and other road traffic metal discharges (Trombulak and Frissell 2000). The same scenario was used to evaluate characteristics related to tree biomass stocking. For estimating biomass stocks, a total of 24 dominant tree species with nearly identical height and girth were randomly selected from each site.

A hand auger was used to gather 60 surface soil samples (0-20 cm depth), each weighing $0.5 \mathrm{~kg}$. The soil samples were securely packaged, tagged, and sent to Tezpur University's Ecology and Biodiversity Research Laboratory for pretreatment and analysis. The soil samples were air-dried in a dust-free environment for 2 weeks at room temperature $\left(25^{\circ} \mathrm{C}\right)$, (Singh et al. 2015; Ngaba and Mgelwa 2020), ground with a wooden pestle, and mortar to break soil lumps. The soil samples were sieved through a $2 \mathrm{~mm}$ and homogenized in the laboratory (Singh et al. 2015; Ngaba and Mgelwa 2020), then stored in zip-lock polyethylene bags in desiccators for further digestion and analysis.

\section{Soil physicochemical properties and heavy metal analysis}

Standard techniques and methods were used to examine all of the soil samples. Soil pH, electrical conductivity (EC), and organic carbon (OC), as well as the available N, P, and K contents, were determined using the procedures outlined by Jackson, 1958; Walkley and Black, 1934; Subbiah \& Asija, 1956; Bray \& Kurtg, 1945; Gupta, 2007, respectively). At pH 7.3, soil metal pollutants (Cd and Ni) were extracted with 5 mM diethylenetriaminepentaacetic acid (DTPA)/10, $\mathrm{mM} \mathrm{CaCl} / 100 \mathrm{M}$ triethanolamine (TEA), whereas $\mathrm{Cr}$ and $\mathrm{Pb}$ were extracted with $0.05 \mathrm{M}$ Ethylenediamine tetraacetic acid (EDTA) and ammonium nitrate extraction method at pH 7.0 (Lindsay \& Norvell, 1978). Inductively coupled plasmamass spectrometry (ICP-MS) (PerkinElmer Nex IONTM 300, USA) was used to determine the concentrations of all metal contaminants (Cd, Cr, Ni, and $\mathrm{Pb}$ ) in an aliquot of the filtrate.

\section{Reagents and chemicals quality}

Analytical grade chemicals and reagents with a high spectroscopic purity of $99.9 \%$ were utilised without further purification throughout the laboratory analysis. For reagent dilutions, standards, and sample preparation, double distilled water was employed. Calibration curves were created by diluting benchmark stocks to create standards. Blanks were run regularly to verify that the analysis was of high quality, and washings were supplied at regular intervals (Sharma et al. 2018). Each sample was analyzed three times, and the average values were reported (Adhikari and Bhattacharyya 2015).

\section{Evaluation of metals pollution and Ecological risk assessments}

The use of indices was employed to evaluate metal pollution and determine ecological risks in soil. For quantifying metal contamination in soil, various index approaches exist, each with different pollution scales of classification (Sarkar et al. 2011). The present study employed several indices to account for the majority of quantifiable characteristics and provide a realistic estimate of pollution levels and ecological risks (Sarkar et al. 2011; Kaushik et al. 2021). These indices include: (1) geo-accumulation index (Igeo), (Singh et al. 2015; Ngaba and Mgelwa 2020); (2) pollution index (PI), (Tomlinson et al. 1980; Singh et al. 2015); (3) integrated pollution index (IPI), (Singh et al. 2015; Dutta et al. 2021); (4) pollution load index (PLI), (Sarkar et al. 2011); (5) nemerow pollution index (PIN), (Dutta et al. 2021); (6) enrichment index (Cp), Hakanson 1980; Ngaba and Mgelwa 2020); and (7) ecological risk index (RI), (Hakanson 1980; Ngaba and Mgelwa 2020).

\section{Geo-accumulation index (Igeo)}


The geo-accumulation index (Igeo) is a quantitative parameter approach for determining heavy metal contamination in soil. Muller first launched it in 1969 (Adimalla 2020). It assesses the extent of metal pollution in soils (Ngaba and Mgelwa 2020) and allows us to compare current and preindustrial levels (Gowd et al. 2010). The index can also be used to identify lithogenic impacts as a source of metal pollution (Shi et al., 2019). Eq. 1 can be used to calculate the geo-accumulation index (Igeo).

$$
\mathrm{I}_{\text {geo }}=\log _{2}\left[\frac{C_{n}}{1.5 \times B_{n}}\right]
$$

(1)

where $\mathbf{C}_{\mathbf{n}}$ denotes the measured metal pollutant concentration in soil, and $\mathbf{B}_{\mathbf{n}}$ denotes the metal concentration in the geochemical background (i.e., unpolluted sample or in natural forest). The levels of metal accumulation used in this study were: (i) practically uncontaminated (if Igeo $\leq 0$ ); (ii) uncontaminated to moderately contaminated (if $0<$ lgeo $<1$ ); (iii) moderately contaminated (if $1<$ Igeo $<2$ ); (iv) moderately to heavily contaminated (if $2<$ Igeo < 3); (v) heavily contaminated (if $3<$ Igeo < 4); (vi) heavily to extremely contaminated (if $4<$ Igeo $<5$ ) and (vii) extremely contaminated (if $5<$ lgeo $>6)$ ), (cited in Ngaba and Mgelwa (2020, p. 4) and Adimalla (2020).

\section{Pollution index (PI)}

The pollution index $(\mathrm{PI})$ is the ratio of the heavy metal content in the soil sample being tested to the metal's natural background concentration (Dutta et al. 2021). It's commonly expressed as the percentage of the sample's metal content that exceeds that of the reference (unpolluted reference) material (Sarkar et al., 2011). The index measures metal pollution by considering land-use patterns and anthropogenic impacts on soil, and aims to match average metal concentrations in a given soil to a global or local natural background value (Hu et al. 2013; Adhikari and Bhattacharyya 2015). Eq. 2 can be used to determine the pollution index (PI).

$$
\mathrm{PI}=\frac{C_{n}}{B_{n}}
$$

where $\mathbf{C}_{n}$ is the element's measured concentration in soil and $\mathbf{B}_{\mathbf{n}}$ is the local natural background value. Each metal pollutant was classed as: (i) low (if $\mathrm{PI} \leq 1.0$ ); (ii) medium (if $1.0<\mathrm{PI} \leq 3.0$ ) and (iii) high (if $\mathrm{PI}>3.0$ ), (Singh et al. 2015; Dutta et al. 2021).

\section{Integrated pollution index (IPI)}

Because it takes the mean of all measured pollution index (PI), and the integrated pollution index (IPI) provides a thorough assessment of the soil's overall pollution state (Dutta et al. 2021). Eq. 3 was used to compute IPI.

$$
I P I=\sum\left[{ }_{x}^{-} P I\right]
$$

(3)

where $\mathrm{DPI}$ is the average of all PI values measured for each element. The pollution levels were assigned as: (i) low pollution (if IPI $\leq 1.0$ ); (ii) middle pollution (if $1.0<\mathrm{IPI} \leq 2.0$ ); and (iii) high pollution (if IPI > 2.0) to the IPI values (Singh et al. 2015).

\section{Pollution load index (PLI)}

Tomlinson et al., developed the pollution load Index (PLI) as a measure of metal pollutant pollution at each sampling site (Tomlinson et al. 1980). The pollution load index (PLI) is calculated using contamination factors (Cf), which are the nth root of the factors multiplied together for each metal at each location. Its quotient is calculated by dividing each metal's concentration by the background value (Sarkar et al. 2011), and it may be calculated using the following equation: Eq. 4.

$$
P L I=\sqrt[n]{C_{r} n_{1} \times C_{r} n_{2} \times C_{r} n_{3} \times C_{r} n_{4} \cdots \times C_{r} n_{n}}
$$


Where $\mathbf{C}_{\mathbf{r}}$ is the contamination factor of an individual pollutant and $\mathbf{n}$ is the number of metal pollutants that have been analyzed. According to Tomlinson et al. (1980), the value of PLI was divided into seven categories: (i) slight contamination (if $P /<0.25$ ); (ii) moderate contamination (if $0.25 \leq P I<0.5$ ); (iii) severe contamination (if $0.5 \leq P /<1$ ); (iv) slight pollution (if $1 \leq P I<4$ ); (v) moderate pollution (if $4 \leq P I<8$ ); (vi) severe pollution (if $8 \leq P /<16$ ) and (vii) excessive pollution (if $P />16$ ).

\section{Nemerow pollution Index $\left(\mathrm{PI}_{\mathrm{N}}\right)$}

The nemerow pollution index $\left(\mathrm{PI}_{\mathrm{N}}\right)$ was developed to assess the total metal pollution level in surface soils (Hu et al., 2013). It can be calculated as: Eq. 5. It measures the overall contamination degree of soils induced by the overall status of all heavy metals detected.

$$
P I_{N}=\sqrt{\left[\frac{P I_{\text {average }}^{2}+P I_{\text {maximum }}^{2}}{2}\right]}
$$

(5)

where $\mathrm{Pi}_{\text {average }}$ and $\mathrm{PI}_{\text {maximum }}$ are the average and maximum pollution indices for each metal, respectively $\left(\mathrm{Hu}\right.$ et al., 2013). $\mathrm{PI}{ }_{\mathrm{N}}$ values were categorized as follows: (i) considered safe (if PIN<0.7); (ii) precaution domain (if $0.7 \leq \mathrm{PIN}<1.0$ ); (iii) slightly polluted (if $1.0 \leq \mathrm{PIN}<2.0$ ); (iv) moderately polluted (if $2.0 \leq \mathrm{PIN}<3.0$ ) and (v) seriously polluted domain (if PIN > 3.0).

\section{Enrichment index (Cp)}

Only if the mean concentration of a substance exceeds the preindustrial reference value for the substance under examination is it classified as contaminated or enriched (Kumar et al., 2018). The contamination factor (Cf) and degree of contamination (Cd) established by Hakanson (1980) were used to measure the enrichment index (Cp) in surface soil as a result of heavy metals. The contamination factor (Cf) is the proportion of each determined metal pollutant concentration in soils to the specific heavy metal's geochemical background. The total of all contamination factors for all metals analyzed shows the degree of environmental contamination (Cd) (Hakanson 1980). Thus, Eqs. 6 and 7 can be used to calculate the potential Cf and Cd, respectively.

$$
C f=\frac{C_{0}^{i}}{C_{n}^{i}}
$$

(6)

$$
C d=\sum\left[\frac{C_{0}^{i}}{C_{n}^{i}}\right]
$$

(7)

Where $\mathbf{C}_{\mathrm{o}}$ is the mean concentration of an individual metal (e.g., $\mathrm{Cd}, \mathrm{Pb}, \mathrm{Cr}, \mathrm{Pb}$ ) and $\mathbf{C}_{\mathbf{n}}$ is the substance's preindustrial reference value (or natural forest concentration of the individual metal. The values of contamination factor (Cf) were classified as: (i) low contamination factor (if $C \leq 1$ ); (ii) moderate contamination factor (if $1 \leq C<3$ ); (iii) considerable contamination factor (if $3 \leq C<6$ ); and (iv) very high contamination factor (if $C \geq 6$ ). While the degree of contamination (Cd) was divided into four categories: (i) low degree of contamination (if $C d<8$ ); (ii) moderate degree of contamination (if $8 \leq C d<16$ ); (iii) considerable degree of contamination (if $16 \leq C d<32$ ); and (iv) very high degree of contamination (if $C d \geq 32$ ), (Hakanson 1980).

\section{Ecological risk index (RI)}

The ecological risk index (RI), which comprises the aggregate of risk indicators, was used to assess the overall possible ecological risk (Hakanson 1980; Hu et al., 2013). It assesses the ecosystem's total ecological risks by taking into account their particular toxic response elements (Hakanson 1980; Dutta et al. 2021). The potential ecological (RI) effectively assigns the overall ecological risk of several metals in a given environment (Shi et al. 2019), which is a useful indicator of the risk factor for ecology. As a result, the potential ecological risk index (RI) was calculated as the sum of individual metal risk factors (Er): Eqs. 8 and 9. 
(8) $R I=\Sigma\left(E_{i}\right)$

$$
E_{i}=T_{i} \times f_{i}=T_{i}\left[\frac{C_{i}}{B_{i}}\right]
$$

(9)

Where $E_{\mathbf{i}}$ denotes the risk factor, $T_{\mathbf{i}}$ denotes the toxic-response factor for a specific metal, and $\mathbf{f}_{\mathbf{i}}$ denotes the pollution index. To assess $R \mathrm{I}$, standardized toxic response factor values of 30, 5, 2, and 5 were employed for $\mathrm{Cd}, \mathrm{Pb}, \mathrm{Cr}$, and Ni, respectively (Hu et al. 2013; Adhikari and Bhattacharyya 2015; Borah et al. 2018; Dutta et al. 2021). RI values were categorized into four classes: (i) low ecological risk (if RI< 180); (ii) moderate ecological risk (if $150 \leq \mathrm{RI}<300$ ); (iii) considerable ecological risk (if $300 \leq \mathrm{RI}<600$ ); and (iv) very high ecological risk (if RI $\geq 600$ ). According to Hakanson (1980), $\mathrm{E}_{\mathrm{i}}$ 's potential ecological risk was divided into five categories: (i) low potential ecological risk (if $E<40$ ); (ii) moderate potential ecological risk (if $40 \leq E<80$ ); (iii) considerable potential ecological risk (if $80 \leq E<160$ ); (iv) high potential ecological risk (if $160 \leq E<$ 320); and (v) very high potential ecological risk (if $E \geq 320$ ).

Determination of metal geochemical background concentration in soils

The relevant average Indian standard background concentration value of natural soils by Sarkar et al. (2011), Kumar et al. (2018), Adimalla (2020), and Kaur et al. (2020) was used as the natural background value in the study due to the lack of a standard region-specific geochemical baseline for heavy metals comparison values in the Indian region, particularly the studied region.

Estimation of tree biomass stocking potential

Non-destructive approaches were used to evaluate tree biomass stocking potentials aboveground (AGB) and belowground (BGB), (Lasco et al. 2002; Chave et al. 2005; Hangarge et al. 2012; Chave et al. 2014).

The allometric model developed by Nath et al., was used to quantify tree biomass stock (Nath et al. 2019). The use of the model was based on its region specificity for the dry tropical, tropical semi-evergreen, tropical wet evergreen, sub-tropical broad-leaved, and sub-tropical pine forests of northeast India. The global wood density database listed by (Chave et al. 2009) for species-specific was used to assign values for tree species: Eq. $10-13$.

$$
A G B(\mathrm{~kg} / \text { tree })=0.32 \times\left(\mathrm{H} \delta \mathrm{D}^{2}\right)^{0.75} \times 1.34
$$

(10)

Where: $H$ tree height; $\delta$-wood density; and $D$-diameter at breast height.

$$
B G B(\mathrm{~kg} / \text { tree })=A G B \times 0.26
$$

$$
T B(k g / \text { tree })=A G B+B G B
$$

$$
T C(k g / t r e e)=T B \times 0.47
$$

(13)

Where: BGT-belowground biomass; TB-total biomass; $T C$ - tree carbon.

Statistical analysis

The levels of physicochemical characteristics and metal pollutants in surface soils were represented using descriptive statistics. For parametric tests, data were standardized. The Shapiro-Wilk and Levene tests, respectively, were used to verify normality and homogeneity. A one-way ANOVA was used to see if the values of soil characteristics, metals, and tree stocks differed significantly. To see if the differences between the means were statistically significant at $p=0.05$, the Fisher's Least Significant Difference Test (LSD) was used. The correlations and patterns of similarity between metals, soil physico-chemical parameters, and tree biomass stocks were discovered using Pearson's correlation coefficient and hierarchical cluster analysis. The Ward's and Euclidean distance methods were used to make a dendrogram. Empirical models for predicting the effects of metal pollution on tree biomass stocks were developed using stepwise multiple regression analysis. The significant differences in metal pollution levels between roadside and away from roadsides (control) were detected using an independent t-test at a significance level of 0.05 . All statistical analyses were performed using the SPSS Software package (ver. 20.0; SPSS, Chicago, IL).

\section{Results And Discussion}

\section{Physico-chemical properties of soil}


Within sampling sites, the arithmetic means for a few physicochemical parameters ( $\mathrm{pH}$, electrical conductivity (EC), and soil organic carbon (SOC) as well as the available nutrients (nitrogen $(N)$, phosphorus $(P)$, and potassium (K) differed significantly $(F(10,610)=1039.82, p<0.000)$. Table 1 shows the descriptive statistics of the selected soil physicochemical parameters (minimum, maximum, arithmetic mean, and standard deviation $($ Mean \pm SD)). The mean \pm SD values from both sampling sites (control and along roadsides) in Bhomoraguri RF were: 6.140.16 and 7.310.14, 0.260 .11 and $0.520 .21,0.670 .35$ and 1.300 .27 for SOC (\%), and 0.260 .11 and 0.520 .21 for EC ( $\mu$ S/cm). Similarly, the available soil nutrients (mg kg-

${ }^{1}$ ) N, P, and K reported from the two samples had mean \pm SDs of 32.642.15 and 19.491.28, 2.940.98 3.651.22, and 27.4419.08 and 12.908.97 for N, $\mathrm{P}$, and $\mathrm{K}$, respectively. Balipara RF, on the other hand, observed a similar tendency of fluctuation in values between the control site and the roadside.

For Bhomoraguri and Balipara RF, the independent $t$-test revealed that the two sampling sites from each forest were statistically significant at $t=$ $-0.57, \mathrm{df}=85.29, \mathrm{p}<0.000$; and $\mathrm{t}=40.39, \mathrm{df}=94.68, \mathrm{p}<0.000$, respectively. In samples taken from control sites, the $\mathrm{pH}$ of the soil was determined to be strong to moderately acidic (5.27 and 6.14), while it was neutral to basic (6.27 and 7.31) in samples collected along the roadsides. The substantial leaching of exchangeable bases in natural forests due to heavy rainfall conditions may have influenced the acidic character of soil examined in the control area. According to Dutta et al. (2021), high leaching and rainy circumstances improve the exchange of bases and may promote the release of protons due to biochemical weathering. The relatively high $\mathrm{pH}(6.27$ and 7.31$)$ in the samples collected along roads, on the other hand, could be due to the fact that discharged metals from automobile lubricants, vehicular emissions, frequent road repair, and road constructions in highly dense and fast-moving trafficked roads, traversing through these RFs, can modify the physicochemical properties of surface soils by de-acidifying and oxidizing them. Acidic soils enhance heavy metal mobility and adsorption in soil particles, while alkaline soils reduce mobility throughout the soil matrix, according to Adhikari \& Bhattacharyya (2015).

Soil organic carbon (SOC) in soil samples collected from the control site ranged from 1.3 to 3.85 , indicating a high amount of organic carbon in soils, whereas those collected along roadsides ranged from 1.01 to $3.01 \%$, indicating a slight decrease in organic carbon in soil samples compared to those collected from the control site. Although the amount of SOC depends on a variety of parameters (texture, climate, vegetation, and land use pattern), metal contaminants discharged along roadsides may have influenced the minor variance seen in this study. These metals may have an impact on litter decomposition, nitrogen exchange, and trace metal concentrations, as well as general soil health. The presence of stable litterfall and decomposition, which were then released from the vegetation in the forest ecosystem, could explain the relatively high level of SOC reported in the control sites. As a result, it plays an important role in improving soil fertility and plant productivity.

Soil electrical conductivity (EC) measured along the roadside was 0.52 and $0.13 \mu \mathrm{S} / \mathrm{cm}$, respectively, compared to 0.26 and $0.07 \mu S / \mathrm{cm}$ at the control site for Bhomoraguri and Balipara RF. The observed differences between the two sampling sites in the investigated forests could be owing to the discharge and leaching of several lime-related metals containing a significant amount of soluble salts. The salt-related slugs, which result from the chemical used in the shattered stone, blended tar to produce tarmac, play a big role when it comes to road repairs and construction. The available $\mathrm{N}, \mathrm{P}$, and $\mathrm{K}$ concentrations vary significantly between the two sampling sites. The levels of $\mathrm{N}$ and $\mathrm{K}$ were found to be higher in samples collected from the control (32.64 and $45.11 \mathrm{mg} \mathrm{kg}^{-1}$ for $\mathrm{N} ; 27.44$ and $14.07 \mathrm{mg} \mathrm{kg}^{-1}$ for $\mathrm{K}$, respectively) than in samples collected from roadsides (19.49 and $26.93 \mathrm{mg} \mathrm{kg}^{-1}$ for $\mathrm{N} ; 12.90$ and $6.61 \mathrm{mg} \mathrm{kg}^{-1}$ for $\mathrm{K}$, respectively) in Bhomoraguri and Balipara RF.

Contrary to popular belief, available $\mathrm{P}$ levels were higher in soil samples taken from roadsides (12.90 and $18.19 \mathrm{mg} \mathrm{kg}^{-1}$, respectively) than in the control sites ( 2.94 and $14.68 \mathrm{mg} \mathrm{kg}^{-1}$ ). The main source of worry about the decreased available $\mathrm{P}$ in the control site might be attributed to the high uptake and fixation of $\mathrm{P}$ by the dominant forest tree species (Tectona grandis), which used and stored a large amount of P. Not only that, but the quick utilisation of iron and aluminium by huge trees and regenerating plants, as documented by (Shrestha and Kafle 2020), could have had a part in the reduction of available $\mathrm{P}$ in the samples from the control sites. Furthermore, high $\mathrm{P}$ availability in soil samples collected near roadsides could be attributed to vehicular discharge of P-related compounds.

\section{The concentration of metal pollutants in surface soils}

The present investigation found a significant difference in metal pollutant concentrations between the two sampling sites (control and along roadsides) at the $95 \%$ level $(t=-33.65, \mathrm{df}=58.37, \mathrm{p}<0.000)$. The metal pollutant evaluated in soil samples collected from two places within the study forests was positive (Table 2). In Bhomoragiri RF, metal concentrations varied from 0.13 to 0.46 and 1.91 to 6.90 mg kg- 1 for Cd; 0.29 to 0.59 and 4.87 to $9.53 \mathrm{mg} \mathrm{kg}-1$ for $\mathrm{Cr} ; 2.83$ to 5.67 and 50.39 to $100.78 \mathrm{mg} \mathrm{kg}-1$ for Ni; and 8.43 to 15.08 and 113.05 to $202.32 \mathrm{mg} \mathrm{kg}-1$ for $\mathrm{Pb}$ in the control site and along roadsides, respectively. In Balipara RF, metal concentrations varied from 0.004 to 0.14 and 0.06 to 2.19 mg kg-1 for Cd; 0.24 to 7.41 and 3.98 to $122.69 \mathrm{mg} \mathrm{kg}-1$ for $\mathrm{Cr} ; 0.36$ to 2.95 and 5.66 to $46.36 \mathrm{mg} \mathrm{kg}-1$ for Ni; and 3.17 to 13.56 and 31.85 to $136.12 \mathrm{mg}$ kg-1 for Pb.

Metal concentrations were greater in soil samples taken along roadsides (for example, Ni had a mean of $4.37 \mathrm{mg} \mathrm{kg}^{-1}$ ) than in control locations ( $\mathrm{Ni}$ $\left.=78.01 \mathrm{mg} \mathrm{kg}^{-1}\right)$. Pb had the highest content, with 137.83 and $60.67 \mathrm{mg} \mathrm{kg}^{-1}$ for Bhomoraguri and Balipara RF, respectively, followed by Ni (78.01 and $18.86 \mathrm{mg} \mathrm{kg}^{-1}$ ), and $\mathrm{Cd}$ had the lowest concentration (2.97 and $\left.0.53 \mathrm{mg} \mathrm{kg}^{-1}\right)$.

The mean concentrations of metal contaminants in surface soil were in the sequence $\mathrm{Pb}>\mathrm{Ni}>\mathrm{Cr}>\mathrm{Cd}$ in all of the forests tested. However, for all metals studied, the mean concentration was higher in Bhomoraguri RF than in Balipara RF. This could be owing to the ongoing large-scale bridge construction project along the Brahmaputra River, which runs through the forests. As a result, there are a variety of road diversions in the area, all of

Page 8/22 
which have a serious concern for tree removal to maximize the number of vehicles passing the RF. The creation of these temporary road diversions results in a significant shift in road geometry and vehicle speed. Devi et al. (2019) said that road geometry has a direct impact on vehicle deceleration and acceleration, hence controlling metal pollutant load discharge and emissions from vehicular engines, as well as wear and tear. Despite considerable differences in concentration levels among the examined metal pollutants ( $\mathrm{Cd}, \mathrm{Cr}$, $\mathrm{Ni}$, and $\mathrm{Pb}$ ), the mean concentrations were determined to be below-allowed limits when compared to the Indian standards guideline for natural and roadside soils (Bhatia et al. 2015; Kaur et al. 2020). According to Adimalla (2020) and Kaur et al. (2020), the majority of the examined metals were even lower than the safe level of other international guidelines. For example, the mean $\mathrm{Cd}$ concentration along the roadside in Bhomoraguri and Balipara RF was 2.97 and $0.53 \mathrm{mg} \mathrm{kg}$ 1 , respectively, although the permitted Cd limits in soil for natural and roadside soils vary from 3 to $6 \mathrm{mg} \mathrm{kg}^{-1}$ (Bhatia et al. 2015 ; Kaur et al. 2020). Pb had the widest concentration range (113.05-202.32 $\left.\mathrm{mg} \mathrm{kg}^{-1}\right)$; however, the mean values were lower than the Indian soils' value limitations. The higher concentrations of metal pollutants in soil samples collected along roadsides compared to control sites suggest that the source of these metals could be automobile lubricants discharged due to road repair and construction, break tears, and vehicular emissions caused by road repair and construction fast-moving traffic. Metal contaminants and their compounds could have been released and deposited faster due to these anthropogenic activities. The adsorption and mobility of these meta pollutants in the soil may increase the toxicity of biological systems, lowering plant species production. Mobility of metals such as $\mathrm{Cr}$ is a function of soil $\mathrm{pH}$, oxidizing, and reducing conditions, according to Gowd et al. (2010). Still, Pb varies significantly with soil type and may be released by motor vehicle exhaust fumes. Although the concentration of Cd was lower than that of other metal pollutants, it has a high toxicity profile (Shi et al. 2019); therefore, it should not be overlooked.

The concentrations of metal contaminants found in this study agree with roadside soil and road dust urban parks in Delhi, India, by Siddiqui et al. (2020). Similarly, except for $\mathrm{Pb}$, the concentrations of $\mathrm{Cd}$ and $\mathrm{Cr}$ in the current investigation followed the same trend as the findings reported by Singh et al. (2015) in roadside soils of Varanasi, India. The concentrations of metal contaminants in the present study, on the other hand, were significantly lower than those reported by Devi et al. (2019) in highway road dust traversing through Assam's Kaziranga National Park. Furthermore, it was difficult to establish accurate comparisons from the present study's findings due to a lack of similar studies from the region. However, some metal pollution concentration studies from various land uses in the region were compared for justification (Table 3 ).

Furthermore, the results of this study were compared to published metal pollution concentrations in other Indian states. The results of this investigation matched those published by Adhikari and Bhattacharyya (2015), Bhatia et al. (2015), Kumar et al. (2018), and Kaushik et al. (2021). However, it was discovered in contrast to the findings of Kaur et al. (2020) and Sharma et al. (2018), whose results had a lower concentration than the findings of the present study. The amounts of metal contaminants in the current study, on the other hand, were significantly lower than those reported by Adimalla (2020) in the urban soils of Indian cities. In addition, the results of this study were compared to those of other road-related studies conducted in China, Japan, Greece, and Spain (cited in Devi et al. 2019, p. 1394). There were considerable differences in the concentration of metal contaminants discovered.

The disparities in metal pollutant concentrations observed across all comparisons could be attributable to the different sources of metal pollutants. Some of these investigations were conducted in places that were impacted by industrial pollution, urbanization, or substantial agriculture. Thus, the elevated concentration could be attributable to the outflow of industrial wastewater, home sewage, and fertilizer applications. However, as previously stated, the empirical reason for substantial augmentation from the present investigation is difficult to identify because the current study dealt with soil samples polluted mainly by a single source of anthropogenic activity (i.e., vehicular emissions and automobile discharge). According to Shi et al. (2019), the concentration of metal pollutants is influenced by the dominant anthropogenic activity in a given location. For example, in agricultural areas, the use of $\mathrm{Cd}$-containing phosphate fertilizer could result in high levels of $\mathrm{Cd}$ in the soil. The high concentration of Pb-containing chemicals in a specific ecosystem results from industrialization and motor vehicle emissions into the atmosphere. In majority of the literatures, we looked at, we found considerable concentrations of metals along the roadside. For example, Pb concentrations in China ranged from 77.3 to 408 $\mathrm{mg} / \mathrm{kg}$; Greece had a mean of $301 \mathrm{mg} / \mathrm{kg}$; and Spain had a mean of $514 \mathrm{mg} \mathrm{kg}^{-1}$ (Table 3). As a result, the greater concentrations of metals like Pb (ranging from 31.85 to $202.32 \mathrm{mg} \mathrm{kg}^{-1}$ ) and $\mathrm{Ni}$ (5.66 to $100.78 \mathrm{mg} \mathrm{kg}^{-1}$ ) in our study, particularly on roadways, support the hypothesis that they are the result of automotive discharge and motor vehicle emissions. This concentration could reach uncontrollable levels, causing environmental damage to nearby species. Excess Nickel ( $\mathrm{Ni}$ ) in soils, for example, causes a variety of physiological and macroscopic responses, including chlorosis and necrosis, which impede plant development and root growth and inhibit the growth of primary roots (Adimalla 2020). Furthermore, according to the US Department of Health and Human Services' Priority List of Hazardous Substances, metals such as lead (Pb) rank second, cadmium (Cd) rank seventh, and hexavalent chromium ( $\mathrm{Cr}(\mathrm{Vi})$ ) rank seventeen based on prevalence, toxicity, and possible harm (Jha et al. 2016). These metals are among the top twenty on the list, and their persistence in the environment makes them potentially dangerous. As a result, their accumulation in surface soils and subsequent transmission from soil to plants is a major worry (Malik et al. 2010).

\section{Evaluation of metals pollution and Ecological risk assessments}

Table 4 shows the results of the geo-accumulation Index (Igeo) and pollution index (PI) values for the metal contaminants studied. In Bhomoraguri $\mathrm{RF}$, the Igeo values for $\mathrm{Cd}, \mathrm{Cr}, \mathrm{Ni}$, and $\mathrm{Pb}, \mathrm{Ni}$ were $0.86,-4.44,0.87$, and 2.79 , respectively. While at Balipara $\mathrm{RF}, \mathrm{Cd}, \mathrm{Cr}$, $\mathrm{Ni}$, and $\mathrm{Pb}$ values were -2.09 , $-3.82,-1.40$, and 1.46 , respectively. In all of the forests tested, the Igeo values of the assessed metal pollutant along highways varied significantly, 
ranging from uncontaminated to moderately contaminated, and moderately contaminated to heavily contaminated levels. However, all soil samples collected from the control site (away from roads) exhibited uncontaminated levels (i.e., Igeo $\leq 0)$. Pb $(2<\operatorname{lgeo}<3)$ was found to have the highest environmental contamination in the surface soils by metal contaminants within sites, whereas $\mathrm{Cr}$ and $\mathrm{Cd}$ had the lowest levels. The mean values for $\mathrm{Cd}, \mathrm{Cr}$, Ni, and $\mathrm{Pb}$ along roadsides were 2.97, 0.07, 2.82, and 10.52 in Bhomoraguri RF, and 0.53, 0.18, 0.68, and 4.63 in Balipara RF, respectively, based on an overall assessment of soil samples with respect to the pollution Index (PI). The studied soils revealed three graded levels of pollution according to the PI criteria (i.e, low, medium, and high levels). $\mathrm{Pb}(10.52 \pm 2.07$ ) had the highest amount of pollution, followed by $\mathrm{Cd}$ and $\mathrm{Ni}$, and the lowest level was observed by $\mathrm{Cr}(0.07 \pm 0.02)$ in Bhomoraguri $\mathrm{RF}$, according to the findings. All metals (Cd, $\mathrm{Cr}$, and $\mathrm{Ni})$ were classed as low levels of pollution in Balipara RF, with mean values of $0.53,0.18$, and 0.68 , respectively, with the exception of $\mathrm{Pb}$, which was categorized as a high level of pollution with a mean value of 4.63 . Overall contamination was in the following order: $\mathrm{Pb}>\mathrm{Ni}>\mathrm{Cd}>\mathrm{Cr}$. This indicated that the surface soils along roads traveling through these Reserved Forests were moderately to heavily contaminated, with $\mathrm{Pb}$ and Ni being the primary contaminants. The high concentrations and abundance of $\mathrm{Pb}$ and $\mathrm{Ni}$ in surface soils around roads could be accredited to automotive emissions and automobile discharges due to periodic road repairs and construction.

Table 5 summarizes the nemerov index $\left(\mathrm{PI}_{\mathrm{N}}\right)$ results and the ecological risk index $\left(\mathrm{E}_{\mathrm{i}}\right)$. The analyzed metal pollutants in the surface soils, according to the categories defined by $\mathrm{Hu}$ et al. (2013) for the Nemerov Index $\left(\mathrm{PI}_{\mathrm{N}}\right)$, showed that $\mathrm{Cd}, \mathrm{Ni}$, and $\mathrm{Pb}$ were seriously polluting, while $\mathrm{Cr}$ was in the safe category in Bhomoraguri RF, with mean values of 5.31, 3.25, 13.21, and 0.09, respectively. In Balipara RF, however, there was a slight pollution for $\mathrm{Cd}$ (1.59) and $\mathrm{Ni}(1.28)$ as well as a substantial pollution for $\mathrm{Pb}$ (8.04). These findings imply that $\mathrm{Pb}, \mathrm{Cd}$, and $\mathrm{Ni}$ contribute significantly to environmental pollution. In Bhomoraguri RF, the results of the ecological risk index revealed that Cd was the most significant contributor to ecological risk, with a mean concentration of 88.97, followed by $\mathrm{Pb}(\mathrm{Ei}=52.61)$, $\mathrm{Ni}(\mathrm{Ei}=14.08)$, and finally $\mathrm{Cr}(\mathrm{Ei}=0.14)$. Meanwhile, for $\mathrm{Cd}, \mathrm{Cr}$, Ni, and $\mathrm{Pb}$, the ecological risk mean values in Balipara RF were 1.02, $0.02,0.22$, and 2.31, respectively. According to Hakanson's criteria of 1980 for ecological risk assessment (if $80 \leq \mathrm{Ei}<160$ ) and if $40<\mathrm{Ei} \leq 80)$, Cd (88.97) and $\mathrm{Pb}(52.61)$ were found in the categories of considerable potential ecological risk and moderately potential ecological risk, respectively, in the analyzed soil samples in Bhomoraguri RF. Cr and Ni, on the other hand, were classified as having a low ecological risk. The aggregate mean value of the examined soils in Balipara RF, on the other hand, falls within the category of low ecological risk. Although the overall amounts of metals in Balipara RF were classified as low ecological risk, this result shows that $\mathrm{Cd}$ and $\mathrm{Pb}$ were possible polluting and ecological risk factors in the examined forests. The independent t-test found a statistically significant difference between the two forests analyzed. Apart from road-related discharge and emission, the large variations in potential ecological risks reported in Bhomoraguri RF versus Balipara RF could be attributable to the ongoing bridge construction project and the regular outflow of the Brahmaputra around the Forest Reserve.

According to Tomlinson et al. (1980), the overall site characterization using the pollution load index (PLI) and the integrated pollution index (IPI) revealed that the examined sites (roadsides) in Bhomoraguri and Balipara RF were severely contaminated and highly polluted, respectively. With mean values of 1.43 and 0.69 for Bhomoraguri and Balipara RF, respectively (Table 6). The results on PLI were classed as severe contaminated (if $0.5 \leq P L I<1$ ), while the IPI criteria, classified as high polluted (if $\mathrm{IPI}>2.0$ ), (Singh et al. 2015), with mean values of 16.37 and 6.02 for Bhomoraguri and Balipara RF, respectively. The findings show that national highways passing through RF provide a possible ecological risk to forest surface soils. This suggests that huge amounts of metal contaminants are released into forest soils due to traffic emissions, which could have a considerable influence on species' lifespan. Furthermore, because of their long-term buildup, high concentrations might cause pollution. The end outcome of all of this could pose a major environmental threat. As a result, as Dutta et al. (2021) indicated, monitoring metal concentrations in soils is critical for preventing any anomalous buildup.

The current study's findings are consistent with prior research (Kumar et al. 2018; Devi et al. 2019) that found trace metal accumulation along India's roadsides, as well as pollution and ecological hazards. For example, according to Sarma et al. (2017), roadsides are regularly exposed to metals such as $\mathrm{Pb}, \mathrm{Cd}$, and $\mathrm{Ni}$ due to vehicle emissions on the National Highway. Similarly, Rai et al. (2014) pointed out that vehicle traffic is one of the most significant sources of pollution in the environment. Gowd et al. (2010), metal pollutants such as $\mathrm{Cd}, \mathrm{Ni}$, and $\mathrm{Pb}$ are mostly discharged into the environment through motor vehicle exhaust fumes, automotive discharge, and lead pipe corrosion. Furthermore, Alloway (2012) found that cities provide the greatest levels of $\mathrm{Pb}$ metals in urban soils in the United States. As a result, the deposition of heavy metals along road surface soils may spread to other parts of the environment, with a variety of repercussions, including reduced plant productivity. This is because the uptake of these metals by plants can produce metabolic stress by preventing photosynthesis, respiration, and transpiration (Trombulak and Frissell 2000; Adhikari and Bhattacharyya 2015).

\section{Tree biomass stocking potential}

A total of 24 dominant tree species were quantified for biomass (i.e., 12 trees from each forest) to assess the impacts of the examined metal pollutants $(\mathrm{Cd}, \mathrm{Cr}, \mathrm{Ni}$, and $\mathrm{Pb})$ on tree biomass stocking and production potential in the forests. From the control site and along roadsides of Bhomoraguri RF, totals of $111.05 \mathrm{Mg} \mathrm{ha}^{-1}$ with an average of $9.25 \pm 1.09$ stocking per tree $\left(\mathrm{Mg} \mathrm{tree}^{-1}\right)$ and $97.41 \mathrm{Mg}^{-1}$ with an average of $8.12 \pm$

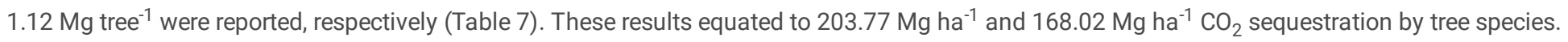

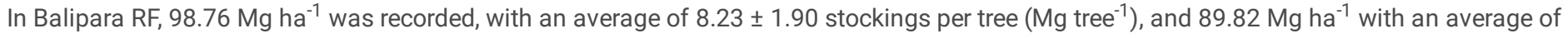


$7.49 \pm 1.85 \mathrm{Mg}^{-1} \mathrm{tre}^{-1}$. The $\mathrm{CO}_{2}$ equivalent value was estimated to be 181.23 and $154.93 \mathrm{Mg} \mathrm{ha}^{-1}$. Tectona grandis L.f. (19.18 Mg ha-1), Artocarpus integer (Thunb.) Merr (12.18 Mg ha-1), Dalbergia sissoo Roxb (11.87 Mg ha-1), and Ficus carica L ( $9.40 \mathrm{Mg}^{-1}$ ) were the tree species that produced the most biomass and carbon stocks in Bhomoraguri RF. The dominant biomass stocks in Balipara RF, on the other hand, were Ficus carica $\mathrm{L}$ (25.20 Mg ha ${ }^{-1}$ ), Mimusops elengi L (17.09 Mg ha ${ }^{-1}$ ), and Stereospermum chelonoides DC (9.99 Mg ha ${ }^{-1}$ ). For Bhomoraguri and Balipara RF, the topmost biomass and carbon accumulator were found in Tectona grandis L.f. and Ficus carica L., respectively. Despite the slight difference in biomass stocking between the control site and the site along roads, an independent sample t-test revealed that the difference was not statistically significant; $t=0.476, d f=60, p=0.636$; and $t=0.298, d f=82, p=0.766$, for Bhomoraguri and Balipara RF, respectively. According to the study, metal pollutants may negatively affect tree biomass stocks and productive potential.

\section{Correlation between physicochemical properties, metal pollutants, and tree biomass stocks}

A Pearson's correlation coefficient ( $r$ ) and hierarchical cluster analysis (CA) were used to determine the degree of a relationship and similarity between metal pollutants, soil physicochemical parameters, and tree biomass stocks. Table 8 and Fig. 2 illustrate the results of the matrix for these variables. The soil metals were shown to be correlated with physicochemical parameters ( $\mathrm{pH}, \mathrm{EC}$, and SOC), as well as available soil nutrients $(\mathrm{N}, \mathrm{P}$, and $\mathrm{K}$ ) at $\mathrm{p}<0.000$. A strong positive association was discovered between pH and metals ( $\mathrm{Cd}(95 \%), \mathrm{Cr}(93 \%), \mathrm{Ni}(80 \%)$, and $\mathrm{Pb}(98 \%))$. In contrast, a weak positive correlation was observed between EC and metals ( $\mathrm{Cd}(18 \%), \mathrm{Cr}(12 \%), \mathrm{Ni}(5 \%)$, and $\mathrm{Pb}(20 \%)$ ). According to the findings, soil pH has a significant impact on metal pollutant concentrations. On the other hand, SOC had a negative relationship with metal pollutants, with $-63 \%$, $-81 \%$, $-86 \%$, and $-67 \%$, respectively, for $\mathrm{Cd}, \mathrm{Cr}$, Ni, and $\mathrm{Pb}$. Similar to available soil nutrients, metal pollutants were strongly negatively correlated, with coefficient ( $r$ ) values of $-73 \%,-83 \%,-84 \%$, and $-74 \%$ for $\mathrm{N} ;-98 \%,-85 \%,-97 \%$ and $-81 \%$ for P; and $-73 \%,-91 \%,-75 \%$, and $-79 \%$ for $\mathrm{K}$. SOC and soil nutrients such as N, P, and K concentrations were shown to be adversely linked with soil metal pollutant concentrations in the present study. This shows that SOC may have a significant impact on the distribution patterns of their enrichments. According to Shi et al. (2019), soil organic matter can operate as a carrier and binding agent for heavy metals or play an important role in their distribution patterns.

The four metals studied ( $\mathrm{Cd}, \mathrm{Cr}, \mathrm{Ni}$, and $\mathrm{Pb}$ ) were significantly associated when correlation analysis was performed. $\mathrm{Cd}$ and $\mathrm{Cr}(94 \%), \mathrm{Cd}$ and $\mathrm{Ni}$ (74\%), Cd and $\mathrm{Pb}$ (97\%), $\mathrm{Cr}$ and $\mathrm{Ni}$ (88\%), $\mathrm{Cr}$ and $\mathrm{Pb}(90 \%)$, and $\mathrm{Ni}$ and $\mathrm{Pb}$ (76\%) were among the metal pollutants that exhibited a very high positive connection in the correlation matrix. The significant positive association found among the metals in this study suggests that these metals have a similar origin. As stated by Siddiqui et al. (2020), this common source could be linked to vehicular emissions, as well as wear and strain on

automotive parts. The four metal contaminants shown to be strongly negatively correlated with tree biomass were found to be. TB-Pb (-80\%), TB-Ni (-79\%), TB-Cr (-76\%), and TB-Cd (-71\%) were the correlation coefficient matrix in order. Metal pollutants are the most important elements impacting plant physiological activity and productivity, which may have an influence on tree biomass stocks, according to a significant negative association discovered between tree biomass stock and metal pollutants. This is backed up by the findings of (Gonçalves et al. 2020), who discovered the impacts of $\mathrm{Cd}$ and $\mathrm{Pb}$ accumulation in various plant tissues, as well as the resulting restrictions on material translocation.

Cluster analysis (CA) was used to find interrelationships and distinguish between clusters and sub-clusters based on their commonalities. As a measure of similarity, the Ward's technique and the Euclidean distance were utilized (Kumar et al. 2018; Shi et al. 2019). It was also utilized to back up the results of the correlations observation using the Pearson correlation coefficient ( $r$ ). Based on Fig. 2, three main clusters (groups) were identified, each with its own set of features. $\mathrm{Cr}, \mathrm{Pb}, \mathrm{Ni}, \mathrm{Cd}$, and $\mathrm{EC}$ belong to the first cluster. The pH, available $\mathrm{N}, \mathrm{SOC}$, and available $\mathrm{P}$ are found in the second cluster, while available $\mathrm{K}$ and tree biomass stock values are found in the third. Cluster one was divided into two sub-groups: $\mathrm{Cr}$, $\mathrm{Pb}$, and $\mathrm{Ni}$ in one, and EC and $\mathrm{Cd}$ in the other. Cluster two was likewise broken into two sub-groups: $\mathrm{pH}$ and available $\mathrm{N}$ in one, and SOC and available $\mathrm{P}$ in the other. The correlation coefficient was found to correspond with the groupings of soil parameters, metal pollutants, and values for tree biomass stocks. This connection grouping supports the idea that the metal contaminants under investigation have common sources of enrichment in surface soils, which could be substantially linked to automotive emissions in this situation.

\section{Predicting the effects of metal pollutant concentrations on tree biomass stocking potential}

A stepwise multiple regression analysis was done to estimate the impacts of metal pollutants $(\mathrm{Cd}, \mathrm{Cr}$, $\mathrm{Ni}$, and $\mathrm{Pb})$ on tree stocking potential (Table

9). The findings revealed that these metals accounted for $63.4 \%$ of the variations in tree biomass $(F(2,28)=27.49, P<0.000)$. Metal concentrations in surface soils have a variable percentage of effects on tree biomass stocks. The uniqueness contributions of the metals (predictors) were significant for $C d(\beta=1.94, t=2.56, P=0.015)$, and $\operatorname{Cr}(\beta=8.23, t=-2.69, P=0.001)$, but not for Ni $(\beta=-0.34, t=-1.32, P=0.198$, and $\mathrm{Pb}(\beta=-0.49, \mathrm{t}=-1.88, \mathrm{P}=0.07)$. The overall regression models revealed a strong negative relationship between metals $(\mathrm{Cd}, \mathrm{Cr}, \mathrm{Ni}$, and $\mathrm{Pb})$ and tree biomass stocks, with linear models $\hat{Y}=36.478+61.488 C d, R^{2}=0.62, p<0.001 ; \hat{Y}=34.488-29.413 C r, R^{2}=0.64, p<0.001 ; \hat{Y}=43.690-$

$0.112 \mathrm{Ni}, \mathrm{R}^{2}=0.63, \mathrm{p}<0.001 ; \hat{\mathrm{Y}}=42.590-0.249 \mathrm{~Pb}, \mathrm{R}^{2}=0.66, \mathrm{p}<0.001 ; \hat{Y}=36.478+61.488 \mathrm{Cd}+(-29.413 \mathrm{Cr})+\left(\mathrm{Cd} \mathrm{Cr}^{*}, \mathrm{R}^{2}=0.63, \mathrm{p}<0.001 ;\right.$ and $\hat{Y}=$ $43.690+(-0.112 \mathrm{Ni})+(-0.249 \mathrm{~Pb})+(\mathrm{Ni} * \mathrm{~Pb}), \mathrm{R}^{2}=0.66, \mathrm{p}<0.00$, for $\mathrm{Cd}, \mathrm{Cr}, \mathrm{Ni}, \mathrm{Pb},\left(\mathrm{Cd}{ }^{*} \mathrm{Cr}\right)$ and $\left(\mathrm{Ni}{ }^{*} \mathrm{~Pb}\right)$, respectively.

Page $11 / 22$ 


\section{Conclusion}

The following findings could be drawn from the present study:

i. In the surface soils near the highways, there is a clear indication of metal pollution enrichment. Although the mean metal pollutant concentrations ( $\mathrm{Cd}, \mathrm{Cr}, \mathrm{Ni}$, and $\mathrm{Pb}$ ) were within the permitted levels of the Indian standards guideline for natural and roadside soils, However, soil samples obtained near roadsides had higher concentrations of these metals (e.g., $137.83 \mathrm{mg} \mathrm{kg}^{-1}$ for Pb) than those collected in control locations (10.27 mg kg-1 for $\mathrm{Pb}$ ). The findings show that the National Highway (NH-15), which runs through the RFs of Bhomoraguri and Balipara, considerably impacted metal levels in the surface soils. As a result, the primary sources of these metals were automotive lubricants discharged owing to road repair and construction, break tears and vehicular emissions.

ii. Apart from the pollution caused by fast-moving traffic, the large ongoing project of bridge construction across the Brahmaputra River may have facilitated the enrichment of metal pollutants because the construction has resulted in the formation of several road diversions around it, all of which have a great concern for tree clearance to increase the number of vehicles traversing the forests. The creation of these temporary road diversions results in a significant shift in road geometry and vehicle speed. As a result, the vehicle's acceleration is affected, which increases metal pollutant load discharge and emissions from vehicular engines, as well as wear and tear. The adsorption and mobility of these meta pollutants in surface soils may increase soil toxicity for biological systems, lowering plant species production.

iii. The soils in this study were classified as uncontaminated, moderately contaminated, and heavily contaminated based on geo-accumulation index (Igeo) values; results on pollution index $(\mathrm{Pl})$ values for the investigated soils revealed three categories (i.e., low, medium and high polluted category).

iv. In all soil samples, the nemerov index $\left(\mathrm{PI}_{\mathrm{N}}\right)$ values revealed that $\mathrm{Cd}, \mathrm{Ni}$, and $\mathrm{Pb}$ were highly contaminating metals, whereas $\mathrm{Cr}$ was in the safe range. On the other hand, $\mathrm{Cd}(88.97)$ and $\mathrm{Pb}$ (52.61) were determined to be in the categories of considerable potential ecological risk and moderately potential ecological risk, respectively, according to ecological risk assessment standards. $\mathrm{Cr}$ and $\mathrm{Ni}$, on the other hand, were classified as having a low ecological risk. This finding shows that $\mathrm{Cd}$ and $\mathrm{Pb}$ could be contributing to both pollution and ecological hazards in the forests investigated.

v. In addition, the values of the pollution load index (PLI) and the integrated pollution index (IPI) were calculated. For the study RFs, PLI was classified as severely contaminated (if $0.5 \leq P L I<1$ ) and high polluted (if $I P I>2.0$ ). In general, it can be stated that $\mathrm{Pb}$ was a more significant polluter and contaminant of the environment than other metals. Similarly, with a mean concentration of $88.97, \mathrm{Cd}$ appeared as the leading contributor to ecological risk, followed by $\mathrm{Pb}$ (52.61), $\mathrm{Ni}$ (14.08), and $\mathrm{Cr}(0.14)$. The contamination was in the following order: $\mathrm{Pb}>\mathrm{Ni}>\mathrm{Cd}>\mathrm{Cr}$. The findings show that national highways passing through RF provide a possible ecological risk to forest surface soils. This suggests that traffic emissions introduce huge amounts of metal contaminants into forest soils, potentially affecting the lives of plants and animals.

vi. Within metal pollutants, the correlation matrix revealed a positive connection for $\mathrm{Cd}$ and $\mathrm{Cr}(94 \%), \mathrm{Cd}$ and $\mathrm{Ni}(74 \%), \mathrm{Cd}$ and $\mathrm{Pb}$ (97 \%), $\mathrm{Cr}$ and $\mathrm{Ni}(88 \%), \mathrm{Cr}$ and $\mathrm{Pb}(90 \%)$, and $\mathrm{Ni}$ and $\mathrm{Pb}(76 \%)$. A strong positive association found among the metal contaminants in this study suggests that they have a common origin. Similarly, Cluster analysis' correspondence grouping of variables provides evidence that the analyzed metal contaminants have similar sources of enrichment in surface soils. The four metal contaminants that were discovered to be strongly negatively linked with tree biomass were found to be. The correlation coefficient matrix was in the following order: TB-Pb (-80\%), TB-Ni (-79\%), TB-Cr $(-76 \%)$, and TB-Cd (-71\%). According to regression analysis models, metals ( $\mathrm{Cd}, \mathrm{Cr}, \mathrm{Ni}$, and $\mathrm{Pb}$ ) have a strong negative association with tree biomass stocks. Metal pollution were found to be one of the most important elements impacting plant physiological activities and productivity, which could have an impact on tree biomass stocks. As a result, it is critical to create a database of their concentration in soils along roads that pass through protected forests (e.g., Biosphere Reserves (BR), National Parks (NP), Wildlife Sanctuaries (WLS), and Reserved Forests (RF), as well as their potential ecological risk and effects on forest-based ecosystem services.

\section{Declarations}

\section{Declaration of interests}

The authors declare that they have no known competing financial interests or personal ties that may have influenced the work presented in this study.

\section{Funding:}

No fund was received

\section{Acknowledgments}


We gladly acknowledge the Indian Council of Cultural Relations (ICCR) financial support for the first author's fellowship. We appreciate the Forest Department's West Divisional Forest Officer in the Sonitpur district's consent to conduct the study in their Reserved Forests (FSWT/B/Reserved Forests/2019-20/1247-48). Tezpur University's Department of Environmental Sciences provides excellent laboratory facilities, which we greatly appreciate.

\section{Author's contributions}

To this work, all of the authors made major contributions: (1). Gisandu K. Malunguja; was in charge of the fieldwork, collecting, analyzing, and interpreting the data. (2). Bijay Thakur; was responsible for the development of coordinates and maps, as well as the compilation of data (3). Ashalata Devi; supervised the research, provided assistance, typeset, and facilitated all fieldwork-related documents.

\section{Ethical approval:}

Not applicable

\section{References}

1. Adhikari G and Bhattacharyya KG (2015) Ecotoxicological risk assessment of trace metals in humid subtropical soil. Ecotoxicology 24(9):1858-1868. https://doi.org/10.1007/s10646-015-1522-9

2. Adimalla N (2020) Heavy metals pollution assessment and its associated human health risk evaluation of urban soils from Indian cities: a review. Environmental Geochemistry and Health 42(1): 173-190. https://doi.org/10.1007/s10653-019-00324-4

3. Alloway BJ (2013) Sources of Heavy Metals and Metalloids in Soils. In B.J. Alloway (Ed.), Heavy Metals in Soils: Trace Metals and Metalloids in Soils and their Bioavailability 22: 11-50. https://doi.org/DOI 10.1007/978-94-007-4470-7_2

4. Baruah I, Das NG and Kalita J (2007) Seasonal prevalence of malaria vectors in Sonitpur district of Assam, India. Journal of Vector Borne Diseases, 44(2): 149-153.

5. Bhatia A, Singh S, and Kumar A (2015) Heavy Metal Contamination of Soil, Irrigation Water and Vegetables in Peri-Urban Agricultural Areas and Markets of Delhi. Water Environment Research 87(11): 2027-2034. https://doi.org/10.2175/106143015x14362865226833

6. Borah P, Singh P, Rangan L, Karak T and Mitra S (2018) Mobility, bioavailability and ecological risk assessment of cadmium and chromium in soils contaminated by paper mill wastes. Groundwater for Sustainable Development 6: 189-199. https://doi.org/10.1016/j.gsd.2018.01.002

7. Bray RH and Kurtg LT (1945) Determination of total organic and available forms of phosphorus in solis. Soil Sciennce 59:39-45

8. Carvalho MEA., Castro PRC and Azevedo RA (2020) Hormesis in plants under Cd exposure: From toxic to beneficial element? Journal of Hazardous Materials 384: 121434. https://doi.org/10.1016/j.jhazmat.2019.121434

9. Chave J, Andalo C, Brown S, Cairns MA, Chambers JQ, Eamus D, Fölster H, Fromard F, Higuchi N, Kira T, Lescure JP, Nelson BW, Ogawa H, Puig H, Riéra B and Yamakura T (2005) Tree allometry and improved estimation of carbon stocks and balance in tropical forests. Oecologia 145(1): 87-99. https://doi.org/10.1007/s00442-005-0100-x

10. Chave J, Coomes D, Jansen S, Lewis SL, Swenson NG and Zanne AE (2009) Towards a worldwide wood economics spectrum. Ecology Letters 12(4): 351-366. https://doi.org/10.1111/j.1461-0248.2009.01285.x

11. Chave J, Réjou-Méchain M, Búrquez A, Chidumayo E, Colgan MS, Delitti WBC, Duque A, Eid T, Fearnside PM, Goodman RC, Henry M, MartínezYrízar A, Mugasha WA, Muller-Landau HC, Mencuccini M, Nelson BW, Ngomanda A, Nogueira EM, Ortiz-Malavassi E andVieilledent G (2014) Improved allometric models to estimate the aboveground biomass of tropical trees. Global Change Biology, 20(10): 3177-3190. https://doi.org/10.1111/gcb.12629

12. Chetia M, Chatterjee S, Banerjee S, Nath MJ, Singh L, Srivastava RB and Sarma HP (2011) Groundwater arsenic contamination in Brahmaputra river basin: A water quality assessment in Golaghat (Assam), India. Environmental Monitoring and Assessment 173(1-4): 371385. https://doi.org/10.1007/s10661-010-1393-8

13. Devi U, Taki K, Shukla T, Sarma KP, Hoque RR and Kumar M (2019).Microzonation, ecological risk and attributes of metals in highway road dust traversing through the Kaziranga National Park, Northeast India: implication for confining metal pollution in the national forest. Environmental Geochemistry and Health 41(3): 1387-1403. https://doi.org/10.1007/s10653-018-0219-4

14. Dutta N, Dutta S, Bhupenchandra I, Karmakar RM, Das KN, Singh LK, Bordoloi A and Sarmah T (2021) Assessment of heavy metal status and identification of source in soils under intensive vegetable growing areas of Brahmaputra valley, North East India. Environmental Monitoring and Assessment, 193(6): 1-18. https://doi.org/10.1007/s10661-021-09168-x

15. Fajardo C, Sánchez-Fortún S, Costa G, Nande M, Botías P, García-Cantalejo J, Mengs G and Martín M (2020) Evaluation of nanoremediation strategy in a Pb, Zn and Cd contaminated soil. Science of the Total Environment 706:136041. https://doi.org/10.1016/j.scitotenv.2019.136041 
16. Gonçalves AC, Schwantes D, Braga de Sousa RF, Benetoli da Silva TR, Guimarães VF, Campagnolo M.A, Soares de Vasconcelos E and Zimmermann J (2020) Phytoremediation capacity, growth and physiological responses of Crambe abyssinica Hochst on soil contaminated with Cd and Pb. Journal of Environmental Management 262: 110342. https://doi.org/10.1016/j.jenvman.2020.110342

17. Gowd S, Ramakrishna Reddy M and Govil PK (2010) Assessment of heavy metal contamination in soils at Jajmau (Kanpur) and Unnao industrial areas of the Ganga Plain, Uttar Pradesh, India. Journal of Hazardous Materials 174(1-3): 113-

121. https://doi.org/10.1016/j.jhazmat.2009.09.024

18. Guarda PM, Pontes AMS, Domiciano RS, Gualberto LS, Mendes DB, Guarda EA, José EC, da Silva JEC, (2020) Assessment of Ecological Risk and Environmental Behavior of Pesticides in Environmental Compartments of the Formoso River in Tocantins, Brazil. Archives of Environmental Contamination and Toxicology 79:524-536. https://doi.org/10.1007/s00244-020-00770-7

19. Gupta PK (2007) Methods in Environmental Analysis: Water, Soil and Air. $2^{\text {nd }}$ Ed. Agrobios, India, pp. 443.

20. Hakanson L (1980) An ecological risk index for aquatic pollution control.a sedimentological approach. Water Research, 14(8): $975-1001$. https://doi.org/10.1016/0043-1354(80)90143-8

21. Hangarge LM, Kulkarni DK, Gaikwad VB, Mahajan DM and Chaudhari N (2012) Carbon Sequestration potential of tree species in Somjaichi Rai (Sacred grove) at Nandghur village, in Bhor region of Pune District, Maharashtra State, India. Ann Biol Res 3(7): 3426-3429.

22. Hu Y, Liu X, Ba J, Shih K, Zeng EY and Cheng H (2013) Assessing heavy metal pollution in the surface soils of a region that had undergone three decades of intense industrialization and urbanization. Environmental Science and Pollution Research 20(9): 6150-6159. https://doi.org/10.1007/s11356-013-1668-z

23. Jackson ML (1958) Soil Chemical Analysis. Prentice-Hall Inc., Englewood Cliffs, NJ, pp. 498

24. Jha PC, Samal AC, Santra S and Dewanji A (2016) Heavy Metal Accumulation Potential of Some Wetland Plants Growing Naturally in the City of Kolkata, India. American Journal of Plant Sciences, 07(15): 2112-2137. https://doi.org/10.4236/ajps.2016.715189

25. Kaur M, Kumar A, Mehra R and Kaur I (2020) Quantitative assessment of exposure of heavy metals in groundwater and soil on human health in Reasi district, Jammu and Kashmir. Environ Geochem Health 42(1): 77-94. https://doi.org/https://doi.org/10.1007/s10653-019-00294-

26. Kaushik H, Ranjan R, Ahmad R, Kumar A, Kumar, N and Ranjan RK (2021) Assessment of trace metal contamination in the core sediment of Ramsar wetland (Kabar Tal), Begusarai, Bihar (India). Environmental Science and Pollution Research 28(15): 18686-18701. https://doi.org/10.1007/s11356-020-11775-z

27. Khanam R, Kumar A, Nayak AK, Shahid M, Tripathi R, Vijayakumar S, Bhaduri D, Kumar U, Mohanty S, Panneerselvam P, Chatterjee D, Satapathy BS and Pathak H (2020) Metal(loid)s (As, Hg, Se, Pb and Cd) in paddy soil: Bioavailability and potential risk to human health. Science of the Total Environment 699: 134330. https://doi.org/10.1016/j.scitotenv.2019.134330

28. Kumar V, Sharma A, Kaur P, Sidhu GP, Bali AS, Bhardwaj R, Thukral AK and Cerda A (2019) Pollution assessment of heavy metals in soils of India and ecological risk assessment: A state-of-the-art. Chemosphere 216: 449-462. https://doi.org/10.1016/j.chemosphere.2018.10.066

29. Lasco RD, Lales JS, Arnuevo MT, Guillermo IQ, de Jesus AC, Medrano R, Bajar OF and Mendoza CV (2002) Carbon dioxide (CO2) storage and sequestration of land cover in the Leyte Geothermal Reservation. Renewable Energy 25(2): 307-315. https://doi.org/10.1016/S09601481(01)00065-9

30. Lindsay WL and Norvell WA (1978) Development of a DTPA Soil Test for Zinc, Iron, Manganese, and Copper. Soil Science Society of America Journal 42(3): 421-428. https://doi.org/10.2136/sssaj1978.03615995004200030009x

31. Malik RN, Husain SZ and Nazir I (2010) Heavy metal contamination and accumulation in soil and wild plant species from industrial area of Islamabad, Pakistan. Pakistan Journal of Botany 42(1): 291-301.

32. Mishra S and Kumar A (2021) Estimation of physicochemical characteristics and associated metal contamination risk in the Narmada river, India. Environmental Engineering Research 26(1): 1-11. https://doi.org/10.4491/eer.2019.521

33. Nath AJ, Tiwari BK, Sileshi GW, Sahoo UK, Brahma B, Deb S, Devi NB, Das AK, Reang D, Chaturvedi SS, Tripathi OP, Das DJ and Gupta A (2019) Allometric models for estimation of forest biomass in North East India. Forests, 10(103). https://doi.org/10.3390/f10020103

34. Nath MJ, Bora AK, Yadav K, Talukdar PK, Dhiman S, Baruah I and Singh L (2013) Prioritizing areas for malaria control using geographical information system in Sonitpur district, Assam, India. Public Health 127(6): 572-578. https://doi.org/10.1016/j.puhe.2013.02.007

35. Ng CC, Law SH, Amru NB, Motior MR and Radzi BA (2016) Phyto-assessment of soil heavy metal accumulation in tropical grasses. Journal of Animal and Plant Sciences 26(3): 686-693. https://doi.org/10.5281/zenodo.1019169

36. Ngaba M and Mgelwa A (2020) Ecological risk assessment of heavy metal contamination of six forest soils in China. International Journal of Innovation and Applied Studies 30(1): 1-10. https://doi.org/http://www.ijias.issr-journals.org/

37. Protano C, Zinnà L, Giampaoli S, Spica VR, Chiavarini S and Vitali M (2014) Heavy metal pollution and potential ecological risks in rivers: A case study from Southern Italy. Bulletin of Environmental Contamination and Toxicology 92(1): 75-80. https://doi.org/10.1007/s00128-013$1150-0$

38. Rai PK, Chutia BM and Patil SK (2014) Monitoring of spatial variations of particulate matter (PM) pollution through bio-magnetic aspects of roadside plant leaves in an Indo-Burma hot spot region. Urban Forestry and Urban Greening 13(4): 761-770.

Page $14 / 22$ 
https://doi.org/10.1016/j.ufug.2014.05.010

39. Sarkar S, Ghosh PB, Sil AK and Saha T (2011) Heavy metal pollution assessment through comparison of different indices in sewage-fed fishery pond sediments at East Kolkata Wetland, India. Environmental Earth Sciences, 63(5): 915-924. https://doi.org/10.1007/s12665-0100760-7

40. Sarma B, Chanda SK and Bhuyan M (2017) Impact of dust accumulation on three roadside plants and their adaptive responses at National Highway 37, Assam, India. Tropical Plant Research, 4(1): 161-167. https://doi.org/10.22271/tpr.2017.v4.i1.023

41. Saxena R, Nagpal BN, Singh VP, Srivastava A, Dev V, Sharma MC, Gupta HP, Tomar AS, Sharma S and Gupta SK (2014) Impact of deforestation on known malaria vectors in Sonitpur district of Assam, India. Journal of Vector Borne Diseases, 51(3): 211-215.

42. Sharma NBS (2017) Physico-Chemical Analysis of Soil Status of Various Degraded Sites in an around Dimoria Tribal Belt of Assam, India. International Journal of Science and Research (IJSR) 6(6): 849-852. https://www.ijsr.net/archive/v6i6/6061704.pdf

43. Sharma S, Nagpal AK and Kaur I (2018) Heavy metal contamination in soil, food crops and associated health risks for residents of Ropar wetland, Punjab, India and its environs. Food Chemistry 255: 15-22. https://doi.org/10.1016/j.foodchem.2018.02.037

44. Shi C, Ding H, Zan Q and Li R (2019) Spatial variation and ecological risk assessment of heavy metals in mangrove sediments across China. Marine Pollution Bulletin 143: 115-124. https://doi.org/10.1016/j.marpolbul.2019.04.043

45. Shrestha S and Kafle G (2020) Variation of Selected Physicochemical and Hydrological Properties of Soils in Different Tropical Land Use Systems of Nepal. Applied and Environmental Soil Science 2020: 1-6. https://doi.org/10.1155/2020/8877643

46. Siddiqui Z, Khillare PS, Jyethi DS, Aithani D and Yadav AK (2020) Pollution characteristics and human health risk from trace metals in roadside soil and road dust around major urban parks in Delhi city. Air Quality, Atmosphere and Health, 13(11): 1271-1286.

https://doi.org/10.1007/s11869-020-00874-y

47. Singh H, Pandey R., Singh SK and Shukla DN (2017) Assessment of heavy metal contamination in the sediment of the River Ghaghara, a major tributary of the River Ganga in Northern India. Applied Water Science, 7(7): 4133-4149. https://doi.org/10.1007/s13201-017-0572-y

48. Singh H, Yadav M, Kumar N, Kumar A and Kumar M (2020) Assessing adaptation and mitigation potential of roadside trees under the influence of vehicular emissions: A case study of Grevillea robusta and Mangifera indica planted in an urban city of India. PLoS ONE 15(1): 1-20. https://doi.org/10.1371/journal.pone.0227380

49. Singh S, Raju NJ and Nazneen S (2015) Environmental risk of heavy metal pollution and contamination sources using multivariate analysis in the soils of Varanasi environs India. Environmental Monitoring and Assessment 187(6): 1-12. https://doi.org/10.1007/s10661-015-4577-4

50. Subbiah BV and Asija GL (1956) A Rapid Procedure for Estimation of Available Nitrogen in Soil, Current Science 25(8): 259-260.

51. Tomlinson DL, Wilson JG, Harris CR and Jeffrey DW (1980) Problems in the assessment of heavy-metal levels in estuaries and the formation of a pollution index. Helgoländer Meeresuntersuchungen, 33(1): 566-575. https://doi.org/10.1007/BF02414780

52. Trombulak SC and Frissell CA (2000) Review of ecological effects of roads on terrestrial and aquatic communities. Conservation Biology 14(1): 18-30. https://doi.org/10.1046/j.1523-1739.2000.99084.x

53. US EPA (U.S. Environmental Protection Agency), (1999). Integrated Risk Information System (IRIS). National Center for Environmental Assessment, Office of Research and Development, Washington DC, USA.

54. Walkley A and Black I.A (1934) An examination of the degtjareff method for determining soil organic matter, and a proposed modification of the chromic acid titration method, Soil Science 37(1):29-38.

\section{Tables}

Table 1

Descriptive statistics for physico-chemical properties of soil in two sampling sites. 


\begin{tabular}{|c|c|c|c|c|c|c|c|c|c|c|}
\hline \multirow[t]{3}{*}{ Forest } & \multirow[t]{3}{*}{ Soil parameter } & \multicolumn{9}{|c|}{ Sampling sites } \\
\hline & & \multicolumn{4}{|c|}{ Control site } & \multicolumn{5}{|c|}{ Along roadsides } \\
\hline & & Min & Max & Mean & SD & Min & Mx & Mean & SD & P-value \\
\hline \multirow[t]{6}{*}{ Bhomoraguri RF } & $\mathrm{pH}$ & 5.98 & 6.50 & 6.14 & 0.16 & 7.12 & 7.74 & 7.31 & 0.19 & $p<0.000$ \\
\hline & $\mathrm{EC}(\mu \mathrm{S} / \mathrm{cm})$ & 0.18 & 0.44 & 0.26 & 0.11 & 0.36 & 0.88 & 0.52 & 0.21 & $p<0.000$ \\
\hline & SOC (\%) & 1.30 & 2.16 & 1.67 & 0.35 & 1.01 & 1.69 & 1.30 & 0.27 & $p<0.000$ \\
\hline & Available $\mathrm{N}\left(\mathrm{mg} \mathrm{kg}^{-1}\right)$ & 29.4 & 35.70 & 32.64 & 2.15 & 17.55 & 21.31 & 19.49 & 1.28 & $p<0.000$ \\
\hline & Available $\mathrm{P}\left(\mathrm{mg} \mathrm{kg}^{-1}\right)$ & 0.77 & 3.87 & 2.94 & 0.98 & 0.96 & 4.48 & 3.65 & 1.22 & $p=0.001$ \\
\hline & Available $\mathrm{K}\left(\mathrm{mg} \mathrm{kg}^{-1}\right)$ & 1.44 & 63.85 & 27.44 & 19.08 & 0.68 & 30.01 & 12.90 & 8.97 & $p<0.000$ \\
\hline \multirow[t]{6}{*}{ Balipara RF } & $\mathrm{pH}$ & 4.46 & 5.63 & 5.27 & 0.30 & 5.31 & 6.70 & 6.27 & 0.36 & $p<0.000$ \\
\hline & $\mathrm{EC}(\mu \mathrm{S} / \mathrm{cm})$ & 0.03 & 0.11 & 0.07 & 0.02 & 0.06 & 0.22 & 0.13 & 0.05 & $p<0.000$ \\
\hline & SOC (\%) & 1.65 & 3.85 & 2.22 & 0.42 & 1.28 & 3.01 & 1.73 & 0.33 & $p<0.000$ \\
\hline & Available $\mathrm{N}\left(\mathrm{mg} \mathrm{kg}^{-1}\right)$ & 29.4 & 73.60 & 45.11 & 12.26 & 17.55 & 43.94 & 26.93 & 7.32 & $p<0.000$ \\
\hline & Available $\mathrm{P}\left(\mathrm{mg} \mathrm{kg}^{-1}\right)$ & 3.07 & 39.27 & 14.68 & 8.74 & 3.80 & 48.69 & 18.19 & 10.84 & $p=0.006$ \\
\hline & Available $\mathrm{K}\left(\mathrm{mg} \mathrm{kg}^{-1}\right)$ & 4.60 & 42.42 & 14.07 & 7.22 & 2.16 & 19.94 & 6.61 & 3.39 & $p<0.000$ \\
\hline
\end{tabular}

Note: Min- minimum, Max- maximum, SD- standard deviation

Table 2

The measured concentration of metal pollutants in soil $\left(\mathrm{mg} \mathrm{kg}^{-1}\right)$ samples in two different sampling sites.

\begin{tabular}{|c|c|c|c|c|c|c|c|c|c|c|c|c|c|}
\hline \multirow[t]{3}{*}{ Forest } & \multirow{3}{*}{$\begin{array}{l}\text { Soil } \\
\text { parameter }\end{array}$} & \multicolumn{9}{|c|}{ Sampling sites } & \multicolumn{3}{|c|}{$\begin{array}{l}\text { Indian \& other countries } \\
\text { reference limit values for } \\
\text { metal pollutants in soils }\end{array}$} \\
\hline & & \multicolumn{4}{|c|}{ Control } & \multicolumn{8}{|c|}{ Along roadsides } \\
\hline & & Min & Max & Mean & SD & Min & $\mathrm{Mx}$ & Mean & SD & $\begin{array}{l}\mathrm{P} \text { - } \\
\text { value }\end{array}$ & Metal & Value & References \\
\hline \multirow[t]{4}{*}{$\begin{array}{l}\text { Bhomoraguri } \\
\text { RF }\end{array}$} & $\mathrm{Cd}$ & 0.13 & 0.46 & 0.20 & 0.11 & 1.91 & 6.90 & 2.97 & 1.66 & $\begin{array}{l}p< \\
0.000\end{array}$ & $\mathrm{Cd}$ & $3-6$ & $\begin{array}{l}\text { Kaur et al. } \\
2020\end{array}$ \\
\hline & $\mathrm{Cr}$ & 0.29 & 0.58 & 0.39 & 0.10 & 4.87 & 9.53 & 6.39 & 1.59 & $\begin{array}{l}\mathrm{p}< \\
0.000\end{array}$ & & & $\begin{array}{l}\text { Bhatia et } \\
\text { al } 2015\end{array}$ \\
\hline & $\mathrm{Ni}$ & 2.83 & 5.67 & 4.37 & 0.94 & 50.39 & 100.78 & 78.01 & 16.78 & $\begin{array}{l}\mathrm{p}< \\
0.000\end{array}$ & $\mathrm{Cr}$ & $\begin{array}{l}100- \\
200\end{array}$ & $\begin{array}{l}\text { Kumar et } \\
\text { al. } 2018\end{array}$ \\
\hline & $\mathrm{Pb}$ & 8.43 & 15.08 & 10.27 & 2.02 & 113.05 & 202.32 & 137.83 & 27.14 & $\begin{array}{l}\mathrm{p}< \\
0.000\end{array}$ & & & $\begin{array}{l}\text { Jha et al } \\
2016\end{array}$ \\
\hline \multirow[t]{4}{*}{ Balipara RF } & $\mathrm{Cd}$ & 0.004 & 0.14 & 0.034 & 0.03 & 0.06 & 2.19 & 0.53 & 0.53 & $\begin{array}{l}\mathrm{p}< \\
0.000\end{array}$ & $\mathrm{Ni}$ & 100 & $\begin{array}{l}\text { Adimalla, } \\
2020\end{array}$ \\
\hline & $\mathrm{Cr}$ & 0.24 & 7.41 & 1.10 & 1.70 & 3.98 & 122.69 & 16.38 & 28.95 & $\begin{array}{l}\mathrm{p}< \\
0.000\end{array}$ & & & $\begin{array}{l}\text { Dutta et al. } \\
2021\end{array}$ \\
\hline & $\mathrm{Ni}$ & 0.36 & 2.95 & 1.20 & 0.76 & 5.66 & 46.36 & 18.86 & 11.98 & $\begin{array}{l}\mathrm{p}< \\
0.000\end{array}$ & $\mathrm{~Pb}$ & $\begin{array}{l}250- \\
500\end{array}$ & $\begin{array}{l}\text { Kaur et al. } \\
2020\end{array}$ \\
\hline & $\mathrm{Pb}$ & 3.17 & 13.56 & 6.04 & 3.16 & 31.85 & 136.12 & 60.67 & 31.68 & $\begin{array}{l}\mathrm{p}< \\
0.000\end{array}$ & & & $\begin{array}{l}\text { Sharma et } \\
\text { al. } 2018\end{array}$ \\
\hline
\end{tabular}

Note: Min- minimum, Max- maximum, SD- standard deviation

Table 3

Comparative study for metal pollutant concentration in roads from different parts of India and elsewhere

Page 16/22 


\begin{tabular}{|c|c|c|c|c|c|}
\hline Site & $\mathrm{Cd}$ & $\mathrm{Cr}$ & $\mathrm{Ni}$ & $\mathrm{Pb}$ & Sources \\
\hline Vegetable growing area, Northeast India & $0.43-3.24$ & $3.0-15.24$ & $3.3-14.30$ & $6.0-22.9$ & Dutta et al. 2021 \\
\hline Heavy metals in soils of India & 14.16 & 161.42 & 112.41 & 61.87 & Kumar et al. 2018 \\
\hline Soil, Irrigation water and Vegetables of Delhi, India & $2.28-2.51$ & - & - & $21.25-59.38$ & Bhatia et al. 2015 \\
\hline Soil, food crops of Ropar wetland, Punjab, India & $0.22-1.45$ & $0.33-5.93$ & - & $4.31-12.1$ & Sharma et al. 2018 \\
\hline $\begin{array}{l}\text { Groundwater and soils of Jammu and Kashmir, } \\
\text { India }\end{array}$ & - & $10.0-35$ & - & $5.01-40.01$ & Kaur et al. 2020 \\
\hline Soils of Uttar Pradesh, India & - & $\begin{array}{l}161.8- \\
6227.8\end{array}$ & - & $10.1-67.8$ & Gowd et al. 2010 \\
\hline Urban soils from Indian cities, India & $\begin{array}{l}1.16- \\
3194.8\end{array}$ & - & $\begin{array}{l}2.26- \\
7163.2\end{array}$ & $0.86-665.75$ & Adimalla 2020 \\
\hline Humid subtropical soils of Northeat India & - & $5.10-52.94$ & $\begin{array}{l}48.17- \\
99.51\end{array}$ & $100.9-145.3$ & $\begin{array}{l}\text { Adhikari \& Bhattacharyya } \\
2015\end{array}$ \\
\hline Sewage, pond and sediments of Kolkata, India & 2.45 & 21.6 & - & 18.32 & Sarkar et al. 2011 \\
\hline Soils contaminated by paper mill wastes, India & $\begin{array}{l}10.65- \\
31.33\end{array}$ & $41.2-127.47$ & - & - & Borah et al. 2018 \\
\hline $\begin{array}{l}\text { Highway roads' dust at Kaziranga NP, Northeat } \\
\text { India }\end{array}$ & 1.7 & 208.6 & 123.3 & 29.2 & Devi et al. 2019 \\
\hline Sedimentof Ramsar wetland, Bihar, India & - & - & $\begin{array}{l}40.32- \\
55.22\end{array}$ & $86.62-117.7$ & Kaushik et al. 2021 \\
\hline $\begin{array}{l}\text { Roadside soil and dusturban parks in Delhi } \\
\text { city,India }\end{array}$ & - & - & $32.6-102.1$ & $15.5-75.1$ & Siddiqui et al. 2020 \\
\hline Roadside in the soils of Varanasi environs, India & $0.2-1.2$ & $0.1-0.9$ & - & $28-520$ & Singh et al. 2015 \\
\hline Sedimentof the River Ghaghara, Northern India & $0.21-0.28$ & $61.25-87.68$ & $\begin{array}{l}15.29- \\
25.59\end{array}$ & $10.71-14.26$ & Singh et al. 2017 \\
\hline $\begin{array}{l}\text { High ways in China (Shanghai, Xiana, Xianyang } \\
\text { Baoji) }\end{array}$ & $0.13-123$ & $\begin{array}{l}135.63- \\
167.3\end{array}$ & $49-83.98$ & 77.3-408 & In Devi et al. 2019 \\
\hline High ways in Greece (Kavala) & 0.2 & 196 & 58 & 301 & In Devi et al. 2019 \\
\hline High ways in Spain (Aviles) & 22.3 & 42 & - & 514 & In Devi et al. 2019 \\
\hline Roadside traversing through RF of Assam, India & $0.06-6.90$ & $3.98-9.53$ & $\begin{array}{l}5.66- \\
100.78\end{array}$ & $\begin{array}{l}31.85- \\
202.32\end{array}$ & Present study \\
\hline
\end{tabular}

Table 4

geo-contamination index (Igeo) and pollution index (PI) level of metal pollutants in the two studies forests 


\begin{tabular}{|c|c|c|c|c|c|c|}
\hline \multirow[t]{2}{*}{ Forest } & \multirow[t]{2}{*}{ Sites } & \multirow{2}{*}{$\begin{array}{l}\text { Metals } \\
(\mathrm{mg} / \mathrm{kg})\end{array}$} & \multicolumn{2}{|c|}{ Contamination index (Igeo) } & \multicolumn{2}{|c|}{ Pollution index (PI) } \\
\hline & & & Mean \pm SD & level & Mean \pm SD & level \\
\hline \multirow[t]{8}{*}{ S1 } & Control & $\mathrm{Cd}$ & $-3.09 \pm 0.62$ & Uncontaminated & $0.20 \pm 0.11$ & Low \\
\hline & & $\mathrm{Cr}$ & $-8.49 \pm 0.33$ & Uncontaminated & $0.004 \pm 0.001$ & Low \\
\hline & & $\mathrm{Ni}$ & $-3.28 \pm 0.32$ & Uncontaminated & $0.16 \pm 0.03$ & Low \\
\hline & & $\mathrm{Pb}$ & $-0.96 \pm 0.31$ & Uncontaminated & $0.78 \pm 0.15$ & Low \\
\hline & Roadside & $\mathrm{Cd}$ & $0.83 \pm 0.49$ & Uncontaminated to moderately cont. & $2.97 \pm 1.66$ & Medium \\
\hline & & $\mathrm{Cr}$ & $-4.44 \pm 0.34$ & Uncontaminated & $0.07 \pm 0.02$ & Low \\
\hline & & $\mathrm{Ni}$ & $0.87 \pm 0.36$ & Uncontaminated to moderately cont. & $2.82 \pm 0.61$ & Medium \\
\hline & & $\mathrm{Pb}$ & $2.79 \pm 0.26$ & Moderately to heavenly contaminated & $10.52 \pm 2.07$ & High \\
\hline \multirow[t]{8}{*}{ S2 } & Control & $\mathrm{Cd}$ & $-6.06 \pm 1.34$ & Uncontaminated & $0.03 \pm 0.03$ & Low \\
\hline & & $\mathrm{Cr}$ & $-7.87 \pm 1.15$ & Uncontaminated & $0.011 \pm 0.01$ & Low \\
\hline & & $\mathrm{Ni}$ & $-5.38 \pm 0.87$ & Uncontaminated & $0.04 \pm 0.03$ & Low \\
\hline & & $\mathrm{Pb}$ & $-1.86 \pm 0.66$ & Uncontaminated & $0.46 \pm 0.24$ & Low \\
\hline & Roadside & $\mathrm{Cd}$ & $-2.09 \pm 1.30$ & Uncontaminated & $0.53 \pm 0.52$ & Low \\
\hline & & $\mathrm{Cr}$ & $-3.82 \pm 1.20$ & Uncontaminated & $0.18 \pm 0.03$ & Low \\
\hline & & $\mathrm{Ni}$ & $-1.40 \pm 0.88$ & Uncontaminated & $0.68 \pm 0.43$ & Low \\
\hline & & $\mathrm{Pb}$ & $1.46 \pm 0.67$ & Moderately contaminated & $4.63 \pm 2.42$ & High \\
\hline
\end{tabular}

Note: S1- Bhomoraguri RF, S2- Balipara RF, SD- standard deviation

Table 6

pollution load index (PLI) and integrated pollution index (IPI) values of metal pollutant in the two studies forests

\begin{tabular}{llllll} 
Forest & Sites & \multicolumn{2}{l}{ Pollution Load Index (PLI) } & \multicolumn{2}{l}{ Integrated Pollution Index (IPI) } \\
\hline & & Mean \pm SD & level & Mean \pm SD & level \\
\hline Bhomoraguri RF & Control & $0.00016 \pm 0.0001$ & Slightly contaminated & $1.14 \pm 0.29$ & Middle polluted \\
\hline & Roadside & $1.43 \pm 1.62$ & Severe contaminated & $16.37 \pm 4.20$ & High polluted \\
\hline Balipara RF & Control & $0.000098 \pm 0.0003$ & Slightly contaminated & $0.55 \pm 0.31$ & Low polluted \\
\hline & Roadside & $0.696 \pm 2.25$ & Severe contaminated & $6.02 \pm 3.59$ & High polluted
\end{tabular}

Table 7

Tree-wise biomass, carbon stocks and carbon dioxide equivalent potential (Mg tree $\left.{ }^{-1} \mathrm{ha}^{-1}\right)$ of the two studied forests 


\begin{tabular}{|c|c|c|c|c|c|c|c|c|}
\hline \multirow[t]{2}{*}{ Forest } & \multirow[t]{2}{*}{ Botanical name } & \multirow[t]{2}{*}{ Family name } & \multicolumn{3}{|c|}{ Control site } & \multicolumn{3}{|c|}{ Roadside } \\
\hline & & & TB & $\mathrm{TC}$ & $\mathrm{e}^{\mathrm{TCO} 2}$ & TB & TC & $\mathrm{e}^{\mathrm{TCO} 2}$ \\
\hline S1 & Tectona grandis L.f. & Verbenaceae & 19.18 & 9.59 & 35.20 & 17.33 & 8.15 & 29.89 \\
\hline $\begin{array}{l}\text { Artocarpus } \\
\text { integer(Thunb.) Merr. }\end{array}$ & Moraceae & 12.35 & 6.18 & 22.67 & 10.28 & 4.83 & 17.73 & \\
\hline Dalbergia sissoo Roxb. & Fabaceae & 11.87 & 5.93 & 21.77 & 12.30 & 5.78 & 21.22 & \\
\hline \multirow[t]{10}{*}{ Ficus carica L. } & Moraceae & 9.40 & 4.70 & 17.25 & 7.35 & 3.45 & 12.68 & \\
\hline & Albizia lucidor (Steud.) I.C.Nielsen & Fabaceae & 9.23 & 4.61 & 16.93 & 10.03 & 4.71 & 17.30 \\
\hline & $\begin{array}{l}\text { Duabanga } \\
\text { grandiflora (Roxb. ex DC.) W. }\end{array}$ & Lythraceae & 8.52 & 4.26 & 15.63 & 8.39 & 3.94 & 14.47 \\
\hline & Dillenia indica $\mathrm{L}$. & Dilleniaceae & 7.61 & 3.81 & 13.97 & 5.57 & 2.62 & 9.61 \\
\hline & Shorea robusta Roth & Dipterocarpaceae & 7.55 & 3.77 & 13.85 & 6.49 & 3.05 & 11.19 \\
\hline & Bombax ceiba L. & Malvaceae & 7.03 & 3.51 & 12.89 & 5.38 & 2.53 & 9.28 \\
\hline & Morus laevigata Wall. & Moraceae & 6.57 & 3.29 & 12.06 & 6.32 & 2.97 & 10.90 \\
\hline & Eugenia orbiculata Lam. & Myrtaceae & 5.91 & 2.96 & 10.85 & 3.76 & 1.77 & 6.49 \\
\hline & Ziziphus mauritiana Lam & Rhamnaceae & 5.83 & 2.92 & 10.70 & 4.21 & 1.98 & 7.26 \\
\hline & & Total & 111.04 & 55.52 & 203.76 & 97.41 & 45.78 & 168.02 \\
\hline S2 & Ficus carica L. & Moraceae & 25.20 & 12.60 & 46.24 & 23.69 & 11.13 & 40.86 \\
\hline Mimusops elengi $\mathrm{L}$. & Sapotaceae & 17.09 & 8.54 & 31.35 & 15.87 & 7.46 & 27.37 & \\
\hline \multirow{11}{*}{$\begin{array}{l}\text { Stereospermum } \\
\text { chelonoides DC. }\end{array}$} & Bignoniaceae & 9.99 & 5.00 & 18.33 & 11.04 & 5.19 & 19.04 & \\
\hline & Phyllanthus distichus Müll.Arg. & Phyllanthaceae & 8.43 & 4.22 & 15.48 & 6.56 & 3.08 & 11.32 \\
\hline & Altingia excelsa L. & Altingiaceae & 6.49 & 3.25 & 11.91 & 5.03 & 2.36 & 8.68 \\
\hline & Shorea robusta Roth & Dipterocarpaceae & 6.42 & 3.21 & 11.79 & 5.88 & 2.76 & 10.14 \\
\hline & Millettia pinnata (L.) Panigrahi & Fabaceae & 6.28 & 3.14 & 11.52 & 5.92 & 2.78 & 10.21 \\
\hline & Sterculia villosa Roxb. ex Sm. & Malvaceae & 4.35 & 2.18 & 7.99 & 2.77 & 1.30 & 4.78 \\
\hline & Ficus elastica Roxb. ex Hornem & Moraceae & 4.25 & 2.13 & 7.81 & 3.67 & 1.72 & 6.33 \\
\hline & Baccaurea ramiflora Lour. & Phyllanthaceae & 3.80 & 1.90 & 6.97 & 2.98 & 1.40 & 5.14 \\
\hline & Averrhoa carambola L. & Oxalidaceae & 3.31 & 1.66 & 6.08 & 3.57 & 1.68 & 6.16 \\
\hline & $\begin{array}{l}\text { Castanopsis indica (Roxburgh ex } \\
\text { Lindl.) A. }\end{array}$ & Fagaceae & 3.14 & 1.57 & 5.76 & 2.84 & 1.33 & 4.90 \\
\hline & & Total & 98.76 & 49.38 & 181.23 & 89.82 & 42.22 & 154.93 \\
\hline
\end{tabular}

Note: S1- Bhomoraguri RF, S2-Balipara RF, TB-Tree biomass stock, TC-Tree carbon stock, TCO2 e-Total Carbon dioxide equivalent

Table 8

Correlation between soil physicochemical properties, metal pollutants, and tree biomass stocking potential 


\begin{tabular}{|c|c|c|c|c|c|c|c|c|c|c|c|}
\hline & $\mathrm{pH}$ & EC & SOC & $\mathrm{N}$ & $P$ & $\mathrm{~K}$ & $\mathrm{Cd}$ & $\mathrm{Cr}$ & $\mathrm{Ni}$ & $\mathrm{Pb}$ & $\mathrm{TB}$ \\
\hline $\mathrm{pH}$ & 1 & & & & & & & & & & \\
\hline EC & 0.182 & 1 & & & & & & & & & \\
\hline SOC & $-0.778^{* *}$ & -0.047 & 1 & & & & & & & & \\
\hline $\mathrm{N}$ & $-0.879 * \star$ & -0.104 & $0.934^{\star *}$ & 1 & & & & & & & \\
\hline $\mathrm{P}$ & $-0.966^{\star *}$ & -0.154 & $0.737^{* *}$ & $0.810 * *$ & 1 & & & & & & \\
\hline $\mathrm{K}$ & -0.791 ** & -0.10 & $0.798 * \star$ & $0.863^{\star \star}$ & $0.751^{\star *}$ & 1 & & & & & \\
\hline $\mathrm{Cd}$ & 0.954 ** & 0.181 & $-0.625^{\star \star}$ & $-0.731^{\star \star}$ & $-0.981^{* *}$ & $-0.645^{\star \star}$ & 1 & & & & \\
\hline $\mathrm{Cr}$ & $0.928^{* *}$ & 0.115 & $-0.808^{* *}$ & $-0.825^{\star \star}$ & $-0.981^{* *}$ & $-0.729 * *$ & $0.939 * *$ & 1 & & & \\
\hline $\mathrm{Ni}$ & $0.800 * \star$ & 0.054 & $-0.858 \star \star$ & $-0.844^{\star \star}$ & $-0.852^{\star \star}$ & $-0.908 * \star$ & $0.736^{\star \star}$ & $0.886 * \star$ & 1 & & \\
\hline $\mathrm{Pb}$ & $0.987^{* \star}$ & 0.199 & -0.674 ** & $-0.807 * *$ & $-0.966^{\star \star}$ & $-0.754^{\star *}$ & $0.975^{\star \star *}$ & $0.905^{\star \star}$ & $0.757 \star \star$ & 1 & \\
\hline TB & $-0.730 * \star$ & 0.062 & $0.672^{\star *}$ & $0.739 * \star$ & $0.814^{\star \star}$ & $0.798^{\star \star *}$ & $-0.713^{\star \star}$ & $-0.763^{\star \star}$ & $-0.787 \star \star$ & $-0.801^{\star *}$ & 1 \\
\hline
\end{tabular}

**. Correlation is significant at the 0.01 level (2-tailed).

Note: $\mathrm{pH}$-Soil pH, SOC-Soil organic carbon, $\mathrm{N}$-available nitrogen, P-available phosphorus, K-available potassium, Cd-available Cadmium, Cravailable Chromium, Ni-available Nickel, Pb-available Lead, and TB-Tree biomass stocks.

Table 9

Regression equations to predict the effects of soil metal pollutants on tree biomass

\begin{tabular}{lllll} 
Model & Predictors & \multicolumn{1}{c}{ Regression equations } & R Square & Sig \\
\hline 1. & $\mathrm{Cd}$ & $\hat{\mathrm{Y}}_{\text {effectofCD }}=36.478+61.488 \mathrm{Cd}$ & $\mathrm{R}^{2}=0.62$ & $\mathrm{p}<0.001$ \\
\hline 2. & $\mathrm{Cr}$ & $\hat{\mathrm{Y}}_{\text {effectofCR }}=34.488-29.413 \mathrm{Cr}$ & $\mathrm{R}^{2}=0.64$ & $\mathrm{p}<0.001$ \\
\hline 3. & $\mathrm{Ni}$ & $\hat{\mathrm{Y}}_{\text {effectofNi }}=43.690-0.112 \mathrm{Ni}$ & $\mathrm{R}^{2}=0.63$ & $\mathrm{p}<0.001$ \\
\hline 4. & $\mathrm{Pb}$ & $\hat{\mathrm{Y}}_{\text {effectofPb }}=42.590-0.249 \mathrm{~Pb}$ & $\mathrm{R}^{2}=0.66$ & $\mathrm{p}<0.001$ \\
\hline 5. & $\mathrm{Cd}+\mathrm{Cr}$ & $\hat{\mathrm{Y}}_{\text {effectofCd\&Cr }}=36.478+61.488 \mathrm{Cd}+(-29.413 \mathrm{Cr})+(\mathbf{C d} * \mathrm{Cr})$ & $\mathrm{R}^{2}=0.63$ & $\mathrm{p}<0.001$ \\
\hline 6. & $\mathrm{Ni}+\mathrm{Pb}$ & $\hat{\mathrm{Y}}_{\text {effectof,Ni,\&Pb}}=43.690+(-0.112 \mathrm{Ni})+(-0.249 \mathrm{~Pb})+(\mathrm{Ni} * \mathrm{~Pb})$ & $\mathrm{R}^{2}=0.66$ & $\mathrm{p}<0.001$
\end{tabular}

\section{Figures}




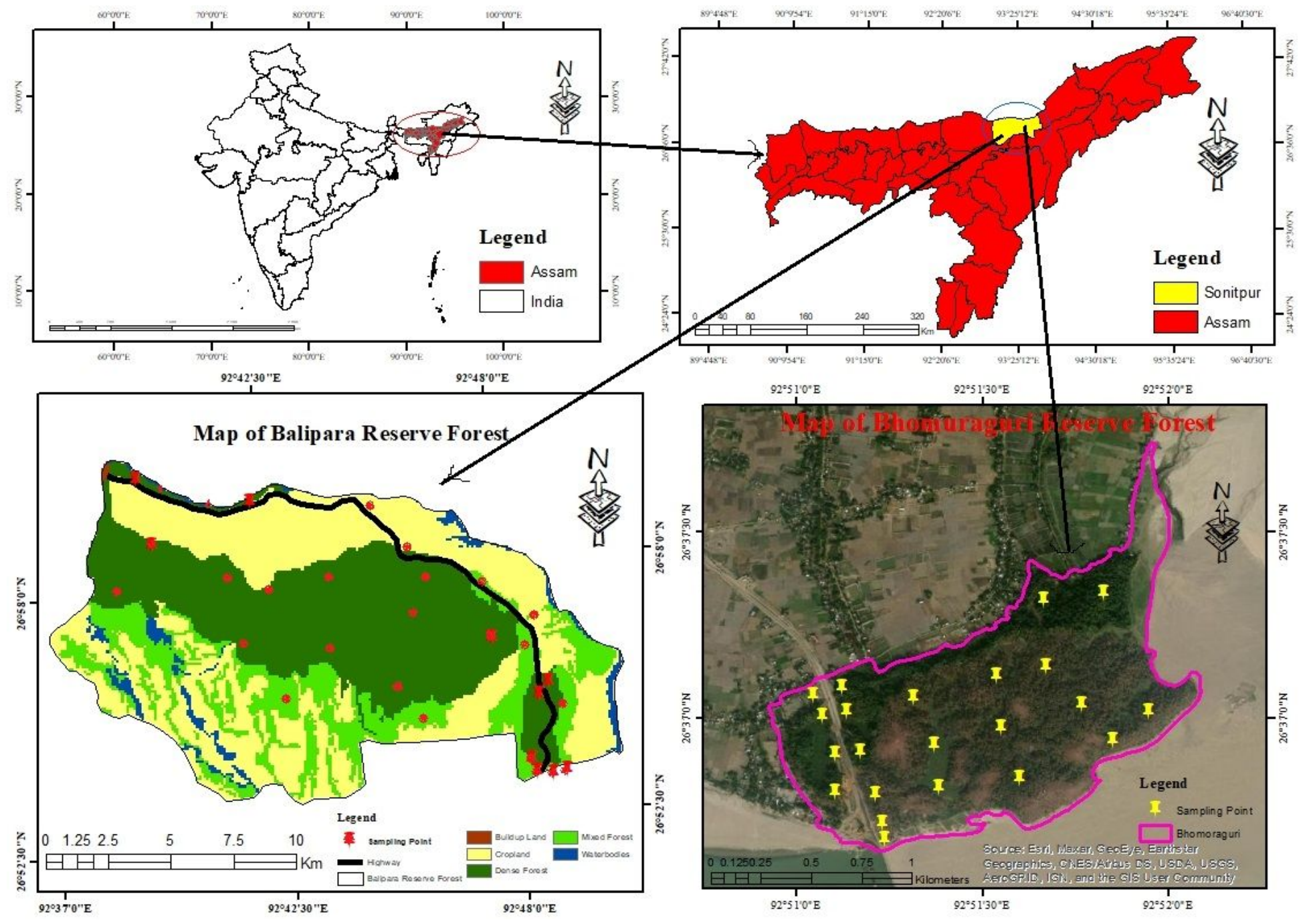

Figure 1

The sketch map to depict the sampling points of the Bhomoraguri and Balipara RFs in Assam, northeast India. 


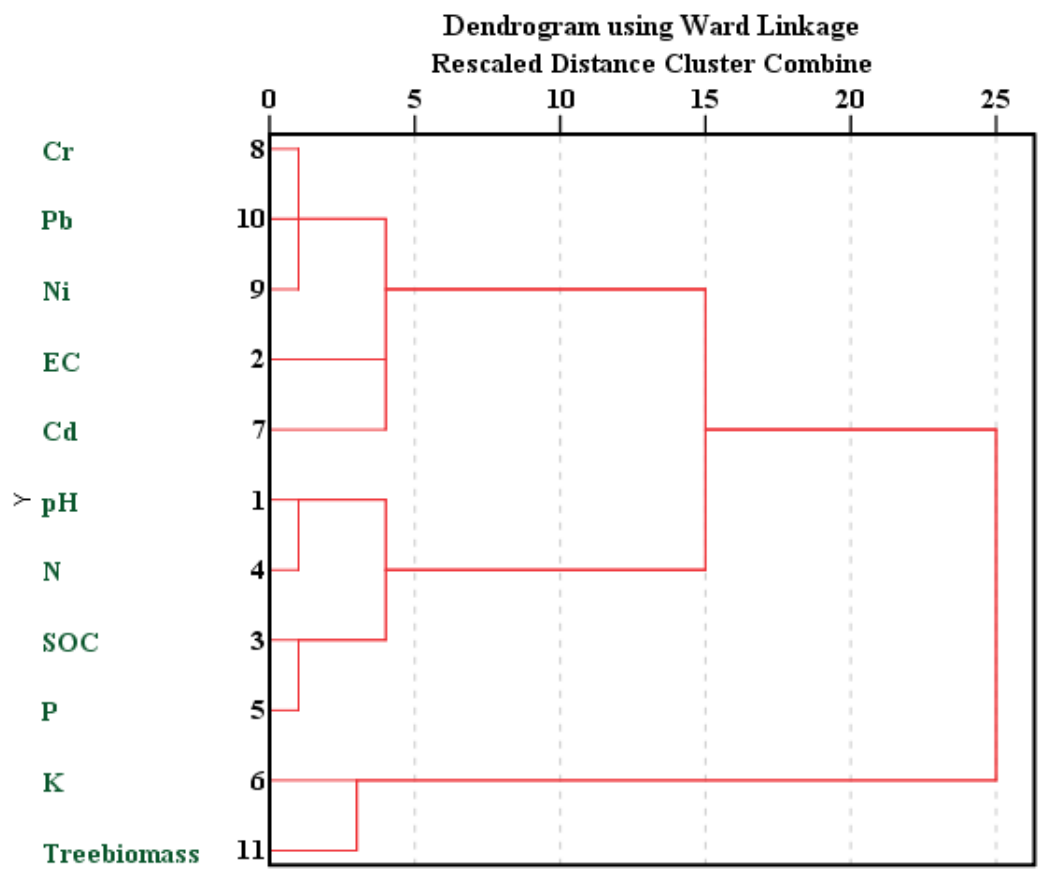

Figure 2

Hierarchical dendrogram depicting the clustering of soil physicochemical properties, metal pollutant and tree biomass stock under investigation 